\title{
Kvaterny majestátů moravských zemských desk Stavovské přijímání na Moravě po roce 1628 a jeho písemná evidence v letech 1642-1852
}

\author{
Jiří Brňovják / jiri.brnovjak@osu.cz \\ Katedra historie, Filozofická fakulta, Ostravská univerzita
}

\begin{abstract}
The essence of the study is an analysis of the so-called "Majestätsquaterne", special series of the Moravian Land Registers (Landtafeln), which recorded the admission of new members to the community of Moravian land estates in the period 1642-1852. As part of this so-called habilitation process in the land, the applicant had to prove that he had an incolat and aristocratic status (by means of an incolat and ennoblement charter), swear a personal oath of loyalty to the monarch (by means of intimation of the Court Chancery) and submit a binding statement in the written form of Relation to the Land (Revers zum Lande) to the land government (i.e., a written oath to uphold the land's constitution, laws, and customs). The study outlines the habilitation process in the land and then goes on to address: the formal and content aspects of the "Majestätsquaterne"; the role of the court and land administrations involved; and individual depositors and the written material produced by them. It reconstructs the practise of registration and shows the resulting compositional scheme of individual registred documents and their classification according to traditional diplomatic categories, including an evaluation of selected internal and external features.
\end{abstract}

\section{Keywords}

Moravia, admission into the Estates, incolat, oath of loyalty to the monarch, Revers to the Land, Majestätsquaterne, Land Registers, $17^{\text {th }}, 18^{\text {th }}$ and $19^{\text {th }}$ century, diplomatic terminology 
Porážka stavovského povstání na Bílé hoře roku 1620 umožnila vítěznému Ferdinandovi II. a jeho straníkům prosadit mnohé z představ o silné panovnické vládě. Některé z nich se dotýkaly otázek společenské mobility ve stavovsky koncipované společnosti. Při přijímání nových členů šlechtických stavovských korporací, vyšší panské a nižší rytířské, sehrávali habsburští panovníci dosud maximálně roli partnerů vlastních stavovských obcí. Tuto nevyváženou kooperaci mezi stavy a panovníkem, v jejímž rámci si právo definitivního rozhodnutí ponechávali sami stavové, se Ferdinand II. rozhodl zvrátit ve svůj prospěch právě po porážce stavovského povstání. Tuto svou vưli nechal vtělit do př́ílušných článků Obnovených zřízení zemských (OZZ), nových zemských ústav, jež byly vydány roku 1627 pro České království a následujícího roku pro Moravské markrabství. ${ }^{1}$ Nová praxe státem kontrolovaného stavovského přijímání, se v následujících desetiletích vyprofilovala v několikastupňový a plně formalizovaný, resp. zbyrokratizovaný proces, na němž se vedle osoby panovníka dále podílela česká dvorská kancelář ve Vídni a příslušné české a moravské nejvyšší zeměpanské úřady (zemské vlády). Zásadní roli při jeho tvorbě sehrálo dotvoření nejvyššího moravského zemského úřadu, tj. královského tribunálu (úřadu zemského hejtmanství) v Brně v 30. letech 17. století, stejně jako stabilizace moravských zemských desk, které byly na počátku 40. let sloučeny do jedné (brněnské) řady a prostřednictvím de facto nově ustaveného deskového úřadu plně postaveny pod královskou kontrolu. ${ }^{2}$ Reorganizace a stabilizace vedení zemských desk současně umožnila převedení evidence stavovského přijímání z vlastní stavovské kompetence do rukou zeměpanské správy a zavedení specializovaných kvaternů, jež byly vzhledem ke svému účelu nazvány Králouské zemské kvaterny majestátů. Následující výklad bude zaměřen na formální i obsahový rozbor této nové řady deskových kvaternů vedené v letech 1642-1852. Pozornost proto bude věnována následujícím tematickým okruhům: (1) stručnému nástinu systému stavovského přijímání; (2) zhodnocení formální a obsahové stránky kvaternů, roli zaangažovaných úřadů i samotného vkladatele (intabulanta) a písemnostem vznikajícím v procesu habilitace v zemi (včetně s ní často spojené nobilitace); (3) rekonstrukci vlastní intabulační praxe a z ní plynoucího skladebného schématu jednotlivých intabulovaných písemností, jež byl typický právě pro vedení kvaternů majestátů (dané písemnosti zde budou nazírány a definovány především z pohledu jejich obsahu a komunikační funkce); (4) klasifikaci jednotlivých intabulovaných písemností z pohledu systematické a analytické diplomatiky: podle tradičních diplomatických kategorií a jejich vybraných vnitřních

1 Ediční zpřístupnění viz Obnovené Právo a Zřizeni Zemské dědičného královstvi Českého. Codex juris Bohemici Tomi V Pars 2. Ed. H. Jireček. Praha 1888; Obnovené zřizení zemské dědičného markrabstvi moravského. Codex Juris Bohemici Tomi 5 Pars 3. Ed. H. Jireček. Brno 1890. Ke zhodnocení obsahu OZZ srov. např. Matějek, František: Účinky Obnoveného zř́zeni zemského z roku 1628. Vlastivědný věstník moravský 42, 1990, č. 3, s. 327-336; Pánek, Jaroslav: Od České konfederace k Obnovenému zř́zení zemskému: (kontinuita a diskontinuita v proměnách českého státu a jeho ústavního zřízení na pomezí stavovství a absolutismu). In: Vývoj české ústavnosti v letech 1618-1918. Sborník příspěvků. Edd. L. Soukup a K. Malý. Praha 2006, s. 13-29 a Malý, Karel: České konfederace a Obnovené zřizeni zemské - dvě české ústavy z počátku 17. století. In: tamtéž, s. 30-44.

2 Brodesser, Slavomír: Správa na Moravě v době absolutismu. In: Morava v době baroka. Sborník příspěvků ze stejnojmenného cyklu přednášek. Ed. T. Knoz 2004, s. 34-38; David, Jiří: Politika na Moravěv době třicetileté války. In: Kryštof Pavel z Liechtensteinu-Castelkornu a Morava v časech třicetileté války. Ed. M. Konečný. Brno 2010, 41-43; Radimský, Jiří: C 4 Tribunál. Sbírka normálii z let 1628-1782. Inventář. Inventáře a katalogy fondů Státního archivu v Brně. Brno 1964, s. x1-x34. 
i vnějších znaků. Studovaná problematika je současně vnímána v kontextu důležité fáze obecného procesu byrokratizace, která v českých (a potažmo i rakouských) zemích probíhala ve 20.-40. letech 17. století, tedy bezprostředně po porážce stavovského povstání. Tehdy vypracovaný systém vertikálně (instančně) i horizontálně vedené písemné úřední komunikace mezi dvorským centrem a nově zřizovanými zemskými úřady (zemské vlády a jejich registratury, později zemské výbory) i stávajícími institucemi (zemské desky) byl v zásadě používán až do zániku stavovské společnosti v polovině 19. století, v zásadních obrysech, avšak zbaven stavovského rozměru, přetrval až do rozpadu monarchie.

\section{Stavovské přijímání od vydání OZZ do poloviny 19. století}

OZZ stanovila pro stavovské přijímání naplnění několika nezbytných právních podmínek. První z nich představoval zisk panovnického souhlasu (Consens) s udělením obyvatelského práva na území celého českého státu. Tento souhlas, jemuž se posléze v kancelár̆ské praxi i právnické mluvě stalo zvykem říkat inkolát (nebo výjimečně, avšak povětšinou analogicky indigenát), byl poskytován formou panovnické listiny. Jeho platnost se výslovně vztahovala na všechny země Koruny české. Inkolát mohl získat pouze šlechtic nejméně rytířského stavu; pokud titul neměl, musel o jeho udělení požádat panovníka - proto řada nešlechtických uchazečů o členství v zemské stavovské obci musela být současně nobilitována. ${ }^{3}$ Za další podmínku stavovského přijímání bylo stanoveno osobní vykonání ústního slibu věrnosti panovníkovi (podle znění OZZ přísaha dědičné poddanosti, něm. Erbhuldigungs-Pflicht/Eid, lat. juramentum fidelitatis) jakožto českému králi, resp. moravskému markraběti, a všem jeho dynastickým nástupcům. ${ }^{4}$ Následně bylo podle OZZ nezbytné osobně se dostavit před úředníky zemských desk a odevzdat vlastnoručně podepsaný a zpečetěný revers k zemi, tj. písemný slib dodržovat zemská práva a zrrízení konkrétní země, mezi jejíž stavy se chtěl dotyčný přihlásit. ${ }^{5}$ Inkolát i revers k zemi byly dědičnými právními akty, platnost reversu se na rozdíl od inkolátu omezovala pouze na konkrétní zemi, do jejíž stavovské obce hodlal jeho vydavatel vstoupit, tedy Čechy nebo Moravu.

3 Obnovené Právo, čl. A.XX; Constitutiones, s. čl. A.X.19. Královský souhlas zde byl primárně určen cizozemcům, avšak posléze se stal nezbytným i pro obyvatele českých zemí, kteří nebyli členy stavovské obce. Z nejnovější literatury k problematice inkolátu a procesu stavovského přijímání viz zejm. Brňovják, Jiří: Šlechticem z moci úřední. Udělování šlechtických titulů v českých zemích 1705-1780. Ostrava 2015, s. 101-128, zejm. 104-115; Starý, Marek: Inkolát. In: Encyklopedie českých právních dějin II. D-J. Edd. K. Schelle a J. Tauchen. Plzeň - Ostrava 2016, s. 806-812. Platnost inkolátu kopírovala historický vývoj hranic českého státu. Proto roku 1651 byli nakonec za cizozemce definitivně prohlášeni obyvatelé obou lužických markrabství, které byly Pražským mírem z roku 1635 uděleny dědičným lénem saskému kurfiřtu Janu Jiřímu. Obě Lužice se nacházely v držení saského kurfiřta již od první poloviny 20. let 17. století, kdy jej Jan Jiří získal do zástavy za svou pomoc s pacifikací lužických a slezských stavovských povstalců. Kalousek, Josef: České státni právo. Praha 1892, s. 148; Kapras, Jan: Právni dějiny zemi Koruny české. Díl třetí: Dějiny státního zřízení. Část druhá: Doba pobělohorská. Praha 1920, s. 26; Zdichynec, Jan: Předáni Lužic Sasku v letech 1620-1635. In: Od konfesijní konfrontace ke konfesijnímu míru. Sborník z konference k 360. výročí uzavření vestfálského míru. Edd. J. Hrbek, P. Polehla a P. Zdichynec. Ústí na Orlicí 2008 s. 70-86.

4 Obnovené Právo, čl. A.II; Constitutiones, čl. A.II.2.

5 Obnovené Právo, čl. A.XX; Constitutiones, čl. A.X.19. 
Složením reversu k zemi, jenž byl v praxi doručován přímo úředníkům zemské vlády a nikoliv - jak vyžadovaly OZZ - zemských desk, byl naplněn požadavek tzv. habilitace v zemi (Habilitierung im/zum Lande). Nově přijatý člen zemské stavovské obce se posléze mohl ohlásit u zemského sněmu k vykázání náležitého místa.

Inkolát i revers $\mathrm{k}$ zemi vycházely $\mathrm{z}$ předbělohorské tradice stavovského přijímání v Čechách a na Moravě; jejich aplikace plně korespondovala s pojetím OZZ založeném na převzetí předbělohorských právních norem a zvyklostí a jejich modifikaci ve prospěch panovníka a jeho zeměpanského aparátu. ${ }^{6}$ Pobělohorskou novinkou byl pouze slib věrnosti panovníkovi, jehož potřeba nepochybně reflektovala nedávno ukončené stavovské povstání. Další upřesnění procesu přijetí mezi zemské stavy přinesly Deklaratoria a novely (DaN), jež byly roku 1640 vyhlášeny pro Čechy a o deset let později přijaty na Moravě. Jejich cílem bylo upřesnění mnohých nejasností nebo příliš obecných nařízení, jež byla uvedena v OZZ. ${ }^{7} \mathrm{~V}$ rámci stavovského přijímání se DaN zabývaly konkrétním průběhem skládání slibu věrnosti panovníkovi. Tu nyní plošně rozšírily na všechny habilitované příslušníky panského a rytířského stavu, kteří dosáhli plnoletosti (20 let), v praxi tedy i na ty, kteří členství ve stavovské korporaci zdědili po svých rodičích a předcích. V případě opakovaného neuposlechnutí nebo liknavosti mohlo dojít k odnětí příslušných stavovských práv. V případě nutnosti, např. pro nemoc nebo kvůli pobytu mimo zemi či monarchii, bylo možno složit slib věrnosti prostřednictvím zplnomocněnce, jímž na Moravě v praxi býval většinou zemský advokát. ${ }^{8}$

Ačkoliv v pobělohorském období bylo v mnoha aspektech společenského i politického života zachováno tradiční dělení šlechtické části stavovské společnosti na rytiřskou a panskou korporaci, resp. jejich novožitnou a starožitnou část, nová právní ustanovení zapříčinila, že státem provozované stavovské přijímání se nyní vztahovalo na šlechtický stav jako celek a z pohledu státního aparátu nebylo tudíž zapotřebí partikulárního přijímání mezi rytíře či pány. Další vnitrostavovský společenský vzestup byl dán postupem po žebříčku vlastních šlechtických titulů, jenž byl ustanoveními OZZ a následných normativů opět garantován panovníkem, resp. jej zastupující kanceláří a podmíněn vydáním patřičné panovnické listiny. ${ }^{9}$ Přestože nové právní podmínky s tradičním přijímáním na zemských sněmech již nepočítaly, nepřivodily zánik tohoto tradičního ceremoniálu. Ten však byl založen pouze na dobrovolné iniciativě vlastních šlechtických obcí, jejíž for-

6 Z literatury zabývající se předbělohorským obdobím nutno připomenout současné nejfundovanější zpracování Starý, Marek: Cizozemci a spoluobyvatelé. Udělování českého obyvatelského práva (inkolátu) v době předbělohorské. Praha 2018.

7 Moderní edici viz Deklaratoria a Novely Obnoveného zřizeni zemského. Edd. K. Malý, J. Šouša a K. Kučerová. In: Vývoj české ústavnosti v letech 1618-1918. Sborník příspěvků. Edd. L. Soukup a K. Malý. Praha 2006,, s. 793-873.

8 Deklaratoria, čl. A.a.1-2, 4 a 5. Do poloviny 18. století habsburští panovníci rozšířili povinnost skládat přísahu také na leníky olomouckého biskupa. Brňovják, J.: Šlechticem, s. 109. K moravským zemským advokátům srov. Komárek, Filip: Moravšti zemšti advokáti v 2. polovině 17. století a jejich knihovny. Diplomová práce, Filozofická fakulta Masarykovy univerzity. Brno 2008. K pravidlům dotýkajících se zemských prelátů stanovených v první polovině 18. století viz Brňovják, Jiří: In vim sanctionis pragmaticae. K interpretaci inkolátní pragmatiky z roku 1713 a nobilitací církevních hodnostářů v českých zemích v 18. století. Historica. Revue pro historii a příbuzné vědy 7,2016, č. 1, s. 1-22.

9 Brňovják, J.: Šlechticem, s. 61-63. 
mální charakter neposkytoval v zásadě žádnou možnost zvrátit již podstoupené úřední přijetí mezi stavy. Na Moravě byla v tomto směru aktivní především rytířská korporace (viz dále). Jak ukazují moravské reálie, nakonec i tento tradiční stavovský rituál podlehl pozvolné degradaci a od počátku 18. století zřejmě zcela zmizel (do jisté míry byl znovuoživen nejpozději na konci téhož století, jistě v souvislosti s reakcí stavovských obcí na reformy josefinského absolutismu). ${ }^{10}$

Popsaný systém stavovského přijímání v Čechách a na Moravě v podstatě fungoval až do revolučních let v polovině 19 . století. ${ }^{11}$ Období josefinských reforem, které byly v mnohém namířeny proti tradičním stavovským institucím, nepřežilo pouze juramentum fidelitatis, jehož zrušení bylo publikováno dvorským dekretem z 26. listopadu $1781 .{ }^{12}$

\section{Evidence habilitace v zemi v deskách zemských}

Byt byla nobilitační, inkolátní a habilitační praxe na základě ustanovení OZZ plně převedena do panovnických rukou, příslušné zeměpanské úřady na zemské úrovni si nevedly žádnou vlastní evidenci osob přijatých mezi české nebo moravské zemské stavy. Císařský dvůr se proto pragmaticky rozhodl využít předbělohorské tradice registrace v příslušných kvaternech zemských desk: v Čechách byla panovnická privilegia zapisována do trhových kvaternů a vlastní přijetí mezi zemské stavy pak do kvaternů relacíi ${ }^{13}$ na Moravě byla od cca roku 1566 vedena zvláštní kniha přijímání mezi rytíre, ${ }^{14}$ na niž v souvislosti s obnovením jednání zemského sněmu a stavovského přijímacího rituálu roku 1628 navázala nová Kniha rytírského stavu. ${ }^{15}$ Až DaN z roku 1640 požadovaly po českých

10 Týž: K úřednimu procesu přijetí do zemské stavovské obce v obdobi od vydáni Obnovených zřízeni zemských do poloviny 19. stoleti a jeho písemnostem. In: Nobilitace ve světle písemných pramenů. J. Brňovják a kol. Ostrava 2009, s. 138-139; David, Jiří: Kniha moravského rytířského stavu (1628-1690). Stavovský rozměr nobilitačního procesu. In: tamtéž, s. 148-159; Dvořák, Rudolf: Jednáni sněmů moravských v letech 1792-1835. Brno 1904, passim. Ke stavovským aktivitám a otázce inkolátu souhrnně Brňovják, J.: Šlechticem, s. 124-125.

11 S výše popsaným procesem habilitace v zemi se setkáme jen na území Českého království a Moravského markrabství, nebot pouze těchto dvou korunních zemí se dotýkala platnost vyhlášených OZZ a pozdějších DaN. Ve Slezsku byla díky ujednání tzv. drážd’anského/saského akordu ze 17. dubna 1621 ponechána v platnosti zemská zřízení jednotlivých knížectví a svobodných stavovských panství, která stavovské přijímání nijak konkrétně neřešila - vycházela z tradičního požadavku držby zemského majetku, který jeho majitele opravňoval k přijetí př́íslušného místa na zemském sněmu, a ze složení nezbytného holdu držiteli knížectví (panovníkovi či lennímu knížeti), resp. svobodného stavovského panství. Brňovják, J.: Šlechticem, s. 115-120.

12 Národní archiv (dále NA), České gubernium IX Publicum, inv. č. 1328, sg. E1/109, kart. 645. Text příslušného dekretu ani jiné studované materiály bohužel neuvádí bližší okolnosti, které Josefa II. k tomuto kroku vedly.

13 NA, Desky zemské, desky zemské větší, inv. č. 1-27 a 127-135, desky zemské stavovské, inv. č. 42-54. Starý, M.: Cizinci, s. 20-21; Burdová, Pavla: Desky zemské 1541-1869. Seznamy kvaternů. Rejstřík. Inventář, Státní ústřední archiv v Praze. Praha 1990, s. 248-249.

14 Moravský zemský archiv (dále MZA), A 3 Stavovské rukopisy, inv. č. 42; Švábenský, Mojmír: Knihy přijímáni do rytiřského stavu Markrabstvi moravského. In: Pilnáček, Josef: Neznámé rody a znaky staré Moravy. Brno 2011, s. 250-253; Hanáček, Jiří: Kniha pánů rytíru markrabstvi moravského. Brno 1986. 
menších zemských úřednících zavedení speciálních kvaternů pro evidenci slibů věrnosti. Ty však byly uvedeny do praxe až roku 1644. Pro další písemnosti byly vzápětí zavedeny další specializované řady knih: od roku 1650 trhové kvaterny majestátů pro opisy listin, v nichž panovník uděloval rytířské a vyšší šlechtické tituly, od roku 1653 trhové kvaterny inkolátů a reversů neboli přiznání se k zemi a stavům. Navíc pro prosté nobilitace byla od roku 1657 otevřena řada kvaternů nobilitací a erbů dání, jež však - vzhledem k charakteru habilitace v zemi - nebyla obligatorní. ${ }^{16}$ Na Moravě byla na základě požadavku instrukce pro deskový úřad z 2. ledna 1642 otevřena nová řada tzv. královských kvaternů majestátů. ${ }^{17}$ Zmíněná desková instrukce bezprostředně navazovala na reformu moravských zemských desk z roku 1641, kdy byly dosavadní separátně vedené řady, brněnská a olomoucká, sloučeny v jednu společnou vedenou v Brně. Díky instrukci byl rovněž dán základ nově konstituovanému úřadu zemských desk jakožto plně zeměpanské (královské) instituci, jenž vedle moravského tribunálu (ustaven 1636) a zemského soudu náležel mezi přední zemské úřady; na rozdíl od tribunálu ale nebyl dvorskému centru podřízen přímo, nýbrž právě prostřednictvím zemské vlády. ${ }^{18}$

Do moravských kvaternů začaly být na rozdíl od českých zemských desk intabulovány jednotně všechny doklady o vykonání všech tří základních požadavků pro habilitaci v zemi. Další rozdíl mezi českými a moravskými kvaterny spočíval ve skutečnosti, že moravské kvaterny s výjimkou prvního svazku (veden v letech 1642-1669) neevidovaly panovnické listiny udílející prostý šlechtický stav. ${ }^{19}$ Samostatné kvaterny slibů věrnosti byly na Moravě nakonec zavedeny až roku 1670, tedy celých dvacet let po rozšíření platnosti DaN i na území Moravského markrabství. Moravské kvaterny př́ísah věrnosti byly vedeny až do zrušení povinnosti př́ísahy roku 1781 a v období jejich existence vzniklo celkem šest knih a několik dalších pomocných repertářů. ${ }^{20}$

Z českých i moravských kvaternů včetně příslušných repertářo̊ (jmenných rejstříků) se tak stal poměrně spolehlivý prostředek evidence všech osob, které se po složení reversu k zemi staly členy moravské stavovské obce s právem přístupu k deskám zemským a tím také s právem manipulace s deskovými statky. Paralelně vedená moravská stavovská Kniha rytiřského stavu byla používána až do roku 1690. Od roku 1694 na ní navázaly další dva rukopisy dokumentující přijímání nových členů moravského rytířského stavu. Zřejmě kvůli duplicitní a finančně o to nákladnější evidenci nově přijatých osob s rytířským

16 Deklaratoria, s. 824; Burdová, P.: Desky (1990), s. 359, 363-364 a 380; Táž: Desky zemské (Rozděleni po stránce obsahové a formální). Sborník archivních prací 43, 1993, s. 362, 398-399.

17 MZA, A 3, inv. č. 59-70 a NA, Česká dvorská kancelář (dále ČDK), inv. č. 1073, sg. VI-B-4, kart. 880. K instrukci viz MZA, B 17 Místodržitelství - patenty, kart. 59, sg. L 3; Demuth, Karl Joseph: Geschichte der Landtafel des Markgrafthumes Mähren. Brünn 1857, s. XCIII-XCIX.

18 Demuth, K. J.: Geschichte, s. 187-208; také srov. literaturu v pozn. 2.

19 Tuto anomálii lze vysvětlit jak neustálenou intabulační praxí v uvedeném období (srov. Kocourek, Jaroslav: Kvatern majestátů z let 1642-1669. Diplomová práce na Filozofické fakultě Masarykovy univerzity. Brno 2002, s. 23-25), tak i postupným upřesňováním habilitačních pravidel: v normativech se nezbytnost minimálně rytířského titulu pro zisk inkolátu prosadila až okolo poloviny 17. století (Brňovják, J.: Šlechticem, s. 112), v praxi - jak ukazuje kvatern A - až s jistým zpožděním.

20 Urbánková, Libuše: A 3 Stavouské rukopisy 1348-1884. Inventář. Moravský zemský archiv v Brně. Brno 1990, s. 19-21. 
titulem v kvaternech majestátů nakonec tato ryze stavovská registrace ztratila své opodstatnění a roku 1719 byla definitivně ukončena. ${ }^{21}$

Soubor Královských kvaternů majestátů moravských zemských desk představuje celkem 12 obsáhlých rukopisných knih, jež byly aktivně používány v letech 1642-1852. Každý svazek byl již v době svého vzniku označen literou. V rámci fondu A 3 Stavovské rukopisy, v němž se tyto rukopisy dnes nacházejí a jenž je deponován v Moravském zemském archivu v Brně, byly kvaternům majestátů přidělena inventární čísla 59-70. Konkrétně jde o kvaterny A (veden v letech 1642-1669), B (1669-1686), C (1686-1701), D (1700-1717, resp. 1734), E (1717-1731), F (1731-1743), G (1743-1755), H (1755-1765), I (1766-1772), K (1773-1785), L (1786-1815) a M (1816-1852). Ke kvaternům majestátů přináležejí také dva svazky repertářů (jmenných indexů) z let 1642-1725 (inv. č. 71) a 1726-1845 (inv. č. 72$).{ }^{22}$

Kvaterny majestátů představují objemné folianty o rozměrech nejčastěji okolo $30 \times 45 \times 10 \mathrm{~cm}$. Lepenkové desky byly potaženy kưží s vyraženým zlaceným rostlinným zdobením. Barva koženého potahu byla zelená, kvaterny C-M byly výslovně označeny jako meergrünes, MEER GRÜN apod. Na předních deskách byl do koženého potahu vyražen zlacený název kvaternů, od kvaternu B stabilně ve znění * KRALOWSKY:ZEMSKY* *MAJESTATUW:KVATERN** LIT.[...]*. Přední desky kvaternů B a K byly navíc vyzdobeny vyraženou a zlatě kolorovanou oválnou kartuší s malým císařským znakem. Všechny kvaterny byly dodatečně zrestaurovány, kvaterny A-C navíc získaly novou textilní převazbu. K uzavření knih byly do vazby vlepeny kožené nebo textilní řemínky. Jednotlivé papírové listy byly průběžně foliovány arabskými číslicemi v pravém horním rohu, pouze v kvaternu M byla na krátko použita paginace (na fol. 46 navazovalo šest foliovaných stran, od fol. 53 opět pokračovala foliace). U většiny kvaternů zůstalo několik prvních a posledních folií nepopsaných a nečíslovaných. Na jednotlivých stránkách byly okraje textu psaného inkoustem vyznačeny tužkou načrtnutou vodící linkou. Vlastní text byl psán černým, popř. hnědým inkoustem. Použité písmo přirozeně podléhalo vývoji dobového vkusu a reflektovalo tedy všechny příslušné vývojové fáze. Vzhledem k drtivé převaze německy psaných listin byla nejčastěji používána novogotická písma. Záhlaví a první řádky dílčích záhlavních regestů stejně jako intabulovaných listin byly psány poměrně zdobnou kaligrafickou frakturou, zatímco pro zbylé řádky díčích záhlavních regestů, zkrácených panovnických intitulací či salutací byla použita novogotická polokurzíva. Obě písma využívala zdobně prodloužené litery, iniciály prvních slov jednotlivých odstavců byly zvýrazněny pomocí složitějších rozvilin. Vlastní text intabulovaných listin pak byl psán kurzívou (kurentem). Novogotické písmo bylo používáno i při intabulaci českojazyčných písemností. Ke zvýrazňování latinských termínů, jež vycházely z dobové právní

21 David, J.: Kniha, s. 153. Na Knihu rytíŕského stavu navázali Protokol rytírů (MZA, A 3, inv. č. 47), veden v letech 1694-1708, a Protokol hofrychtéře (tamtéž, inv. č. 37), veden v letech 1708-1719).

22 Urbánková, L.: A 3 Stavovské rukopisy, s. 13-15. Datace jednotlivých kvaternů, tak jak ji přináší citovaný inventář, jsou poněkud zavádějící. Zohledníme-li primárně datace vkladů, pak např. kvatern A byl ve skutečnosti veden - ve shodě s deskovou instrukcí - až od roku 1642, ačkoliv první intabulovaná písemnost byla vydána již roku 1641; stejně tak poslední dva vklady v kvaternu M byly učiněny roku 1852, intabulované písemnosti ale byly vydány již v letech 1848 a 1849. 
a správní praxe, sloužila humanistická (polo)kurzíva. Největší důraz na kaligrafické ztvárnění písma byl viditelně kladen na intabulace v kvaternu A. Z následujících kvaternů již pozvolna mizí užití fraktury, již nahradila polokurzíva. Až do konce 18. století bylo pro kvaterny majestátů typické pečlivé a díky tomu také velmi dobře čitelné vedení vkladů, přítomnost škrtů či jiných oprav je naprosto minimální. Tato písařská kultura od přelomu 18. a 19. století na krátkou dobu poněkud upadla. Od poloviny 20. let se písaři opět vrátili k honosnějšímu vyhotovení záhlaví, záhlavních regestů dílčích listin a prvních řádků textu listin, v nichž použili frakturu zdobenou rozvilinami.

Jak již bylo naznačeno, dominantním jazykem vkladů byla němčina. Ještě v kvaternech A-C se setkáme s přítomností řady česky psaných písemností či dokonce celých vkladů včetně záhlaví a záhlavních regestů dílčích intabulovaných písemností. Nejvíce celých českojazyčných vkladů bylo učiněno do kvaternu A, stejně jako smíšených německo-českých vkladů, v nichž byla povětšinou přítomna pouze jedna česky psaná dílčí písemnost, zatímco ostatní písemnosti, záhlaví a regesty byly psány německy. Dva česky psané vklady naopak obsahují německé panovnické intimace. ${ }^{23}$ Od počátku 18 . století se stala v podstatě výhradním jazykem intabulací němčina: intabulace dvou francouzských listin (1678, 1812) a jedné latinské (1835) představují zanedbatelnou výjimku, nebot' vklady jako takové byly vedeny německy; v tomto smyslu německý charakter vkladů nenarušují ani jediné dvě česky psané listiny, jež byly vloženy do kvaternu M, a které pocházely z let 1563 a 1608. Jazykovou stránku vkladů do kvaternů majestátů přirozeně ovlivnila již nařízení OZZ, která v úředním styku zrovnoprávnila němčinu s češtinou, která byla doposud používána jako výlučný jednací jazyk. Díky tomu němčina v kancelářské praxi v následujících stoletích naprosto převládla - což ostatně samy kvaterny majestátů dostatečně ilustrují. Je jistě zajímavé, že češtinu zvolila řada nobilitovaných moravských tribunálních či komorních úředníků nebo zemských advokátů, tedy vzdělaných profesionálů, zatímco ostatní zemští a dvorští úředníci upřednostnili němčinu. Zajímavé př́ílady česky psaných vkladů poskytuje zejména skupina př́íslušníků uherské šlechty, která se v průběhu 17. století usídlila na Moravě: Erdödyové (1673), Ledeničtí z Ledenic (1665), Majthényové (1662) a kardinál Jiří Szelepcheny (1668) s jeho příbuzní Maholanyové, Jokayové a Kordičové $(1676,1686,1687,1687) .{ }^{24}$

23 K analýze kvaternu A viz Kocurek, J.: Kvatern, s. 51-52.

24 Brňovják, J.: Stopy uherské nižši šlechty v kvaternech majestátu a slibů vernosti moravských desk zemských od poloviny 17. do poloviny 19. století. In: Zemianstvo na Slovensku v novoveku, I. - Postavenie a majetky zemianskych rodov. Edd. M. Kovačka, E. Augustínová a M. Mačuha. Martin 2010, s. 292-312; týž: Uherská vyšši šlechta v moravských kvaternech majestátů a slibů věrnosti od poloviny 17. do poloviny 19. století. In: Magnátske rody v našich dejinách 1526-1948. F. Federmayer a kol. Martin 2012, s. 186-222. 
Tab. 1: Jazyková stránka intabulací

\begin{tabular}{|l|l|l|l|l|l|l|l|}
\hline Kvatern & Čas. rozpětí & Němčina & Čeština & $\begin{array}{l}\text { Němčina + } \\
\text { čeština }\end{array}$ & $\begin{array}{l}\text { Němčina + } \\
\text { latina }\end{array}$ & $\begin{array}{l}\text { Němčina + } \\
\text { francouzština }\end{array}$ & Celkem \\
\hline $\mathbf{A}(\mathbf{5 9})$ & $1642-1669$ & 133 & 21 & 10 & - & - & 164 \\
\hline $\mathbf{B}(\mathbf{6 0})$ & $1670-1686$ & 59 & 5 & 1 & - & - & 65 \\
\hline $\mathbf{C}(\mathbf{6 1})$ & $1686-1701$ & 49 & 6 & 1 & - & - & 56 \\
\hline $\mathbf{D}(\mathbf{6 2})$ & $1701-1717$ & 69 & - & 1 & - & - & 70 \\
\hline $\mathbf{E}(\mathbf{6 3})$ & $1717-1731$ & 66 & - & - & - & - & 66 \\
\hline $\mathbf{F ~ ( 6 4 )}$ & $1732-1743$ & 53 & - & - & - & - & 53 \\
\hline $\mathbf{G}(\mathbf{6 5})$ & $1743-1755$ & 56 & - & - & - & - & 56 \\
\hline $\mathbf{H}(\mathbf{6 6})$ & $1755-1766$ & 41 & - & - & - & - & 41 \\
\hline $\mathbf{I}(\mathbf{6 7})$ & $1766-1773$ & 45 & - & - & - & - & 45 \\
\hline $\mathbf{K}(\mathbf{6 8})$ & $1773-1785$ & 52 & - & 1 & - & - & 53 \\
\hline $\mathbf{L}(\mathbf{6 9})$ & $1786-1815$ & 109 & - & - & - & 1 & 110 \\
\hline $\mathbf{M ~ ( 7 0 )}$ & $1816-1852$ & 89 & - & 2 & 1 & 1 & 93 \\
\hline
\end{tabular}

Tab. 2: Intenzita využívání kvaternů majestátů

\begin{tabular}{|l|l|l|l|l|l|}
\hline Kvatern & Čas. rozpětí & Počet let & Řádné vklady & Roční průměr & Mimoř. vklady / juxty \\
\hline $\mathbf{A ~ ( 5 9 )}$ & $1642-1669$ & 28 & 162 & 5,8 & 2 juxty $(1675,1694)$ \\
\hline $\mathbf{B}(\mathbf{6 0})$ & $1670-1686$ & 17 & 65 & 3,8 & - \\
\hline $\mathbf{C}(\mathbf{6 1})$ & $1686-1701$ & 16 & 55 & 3,4 & 1 juxta (1700) \\
\hline $\mathbf{D}(\mathbf{6 2})$ & $1701-1717$ & 17 & 69 & 4,0 & 1 mimořádný vklad (1734) \\
\hline $\mathbf{E ~ ( 6 3 )}$ & $1717-1731$ & 15 & 66 & 4,4 & - \\
\hline $\mathbf{F ~ ( 6 4 )}$ & $1732-1743$ & 12 & 53 & 4,4 & - \\
\hline $\mathbf{G ~ ( 6 5 )}$ & $1743-1755$ & 13 & 56 & 4,3 & - \\
\hline $\mathbf{H}(\mathbf{6 6})$ & $1755-1766$ & 12 & 41 & 3,4 & - \\
\hline $\mathbf{I}(\mathbf{6 7})$ & $1766-1773$ & 8 & 45 & 5,6 & - \\
\hline $\mathbf{K}(\mathbf{6 8})$ & $1773-1785$ & 13 & 53 & 4,1 & - \\
\hline $\mathbf{L}(\mathbf{6 9})$ & $1786-1815$ & 30 & 110 & 3,7 & - \\
\hline $\mathbf{M ~ ( 7 0 )}$ & $1816-1852$ & 36 & 93 & 2,6 & - \\
\hline
\end{tabular}

Celkem bylo do kvaternů majestátů učiněno 872 řádných vkladů, tři mimořádné vklady ve formě juxt (dvě v kvaternu A, jedna v kvaternu C) a jeden dodatečný vklad do kvaternu D (zapsán až roku 1734). Tabulka č. 2 přehledně ukazuje časové rozpětí vedení jednotlivých kvaternů i počet uskutečněných vkladů. Mezi nejobsáhlejší patří kvaterny A, L a M, nejméně vkladů bylo zapsáno do kvaternů H a I. Tyto hodnoty však jsou pro značnou odlišnost $\mathrm{v}$ délce vedení jednotlivých kvaternů poněkud zavádějící: např. kvatern A pokrývá období necelých tří desetiletí (nepočítaje v to dvě juxty z let 1675 a 1694) a kvatern M dokonce celých 36 let, zatímco kvaterny F, G, H a K byly používány pouze 12, resp. 13 let a kvatern I jen osm let. Přesnější obrázek proto poskytuje porovnání hodnot, jež ukazuje průměrný roční počet vkladů (do něj nejsou započteny mimořádné vklady): nejvíce jich bylo učiněno do kvaternu A (5,8 vkladu ročně), nejméně do kvaternu M (2,6 vkladů ročně). Obsáhlost kvaternu A lze do jisté míry vysvětlit hledáním optimální formy intabulační praxe, délku vedení kvaternů L a M a s ní spojenou mnohem nižší 
frekvenci zápisů naopak prohlubujícím se poklesem významu habilitace v zemi a spolu s ní i potřeby její systematické evidence. V chronologii vedení jednotlivých kvaternů se s největší pravděpodobností neodráží žádné významné vnější faktory, tj. politické události či správní reformy, změny na postech nejvyšších zemských úředníků apod.; pouze ukončení kvaternu A může souviset se zavedením nové řady kvaternů slibů věrnosti.

\section{Tematická struktura vkladů (obsahová analýza)}

Po obsahové stránce byly nejčastější ty vklady, jež se dotýkaly procesu habilitace v zemi. Tyto vklady lze poměrně jednoduše rozpoznat díky stabilní přítomnosti reversu k zemi, jehož odevzdání úředníkům tribunálu, resp. později moravskoslezského zemského práva či nakonec moravského zemského stavovského výboru ( $\mathrm{k}$ tomu detailněji níže) v zásadě zakončovalo formální proces přijetí mezi moravské zemské stavy. Vlastní obsahová skladba habilitačních vkladů se mohla lišit: značná část z nich registruje podstoupení všech nezbytných kroků, které k habilitaci vedly, tj. nobilitaci, zisk inkolátu, vykonání slibu věrnosti a odevzdání reversu k zemi. V mnoha vkladech naopak panovnické majestáty absentují - mnozí vkladatelé totiž s ohledem na své členství ve stavovské obci některé z dalších zemí Koruny české nemuseli dokládat příslušnost ke šlechtickému stavu a držbu inkolátu. Příchozí cizinci rovněž povětšinou nedokládali svůj šlechtický status a ve svých vkladech se omezovali pouze na prokázání zisku inkolátu, jenž se v druhé polovině 17. století stalo zvykem udílet v konkrétním šlechtickém stavu.

Zcela výjimečně byly do prvních dvou kvaternů učiněny vklady, které dokládaly pouze podstoupení slibu věrnosti panovníkovi. ${ }^{25} \mathrm{~V}$ obou kvaternech totiž byly informace o vykonání juramenta obsaženy v písemnostech habilitačních vkladů a od roku 1670 byly navíc systematicky soustřed’ovány do zvláštní řady kvaternů slibů věrnosti. Obdobně pouze ve třech případech se setkáme s vklady omezenými na registraci odpuštění let (venia aetatis). Jejich cílem bylo získání panovnického souhlasu se zplnoletněním nezletilých dědiců deskových majetků, kteří by pak mohli v zájmu dědického řízení, jež vyžadovalo právo přístupu k zemským deskám, podstoupit řádný proces habilitace v zemi, resp. v případech již habilitovaných členů stavovské obce vykonat nezbytné juramentum fidelitatis. Písemnosti dotýkající se zplnoletnění byly od roku 1670 taktéž výhradně zapisovány do kvaternů slibů věrnosti. ${ }^{26}$

Docela velké množství vkladů se dotýkalo pouze intabulace panovnického privilegia, nejčastěji nobilitační listiny, méně pak již inkolátní listiny či privilegia udělujícího nárok na distinktivní oslovení Hoch- und Wohlgebohren ${ }^{27}$ nebo povolující spojení erbů přídomků šlechtických rodů. ${ }^{28}$ Tyto vklady mohly být učiněny v zásadě jen osobami, které byly

25 MZA, A 3, inv. č. 59, fol. 334v-336r a 351v-353r, inv. č. 60, fol. 182v-183v.

$26 \mathrm{~K}$ pojmu venia aetatis viz Jaksch, Peter Karl: Gesetzlexikon im Geistlichen, Religions- und Toleranzsache, wie auch in Güter-Stiftungs- Studien- und Zensursachen für das Königreich Böhmen von 1601 bis Ende 1800, 2. Prag 1828, s. 522-526 a Ottiov slovnik naučný, XXIV. Praha 1906, s. 545.

27 Např. roku 1663 pro Maxmiliána hraběte Lichtenštejna-Kastelkorna (MZA, A 3, inv. č. 59, fol. 253r-256r).

28 Např. Žerotín-Lilgenau 1743 (MZA, A 3, inv. č. 64, fol. 351r-353r), Waldstein-Wartenberg 1759 (MZA, A 3, 
řádnými členy zemské stavovské obce, a tudíž disponovaly plným přístupem k zemským deskám. Konkrétní motivaci realizace těchto vkladů ze studovaných materiálů nezjistíme. Lze se ale oprávněně domnívat, že zejména u ambiciózních příslušníků nové šlechty šlo o formu nezpochybnitelného pojištění jejich nově nabyté společenské pozice, u tradiční aristokracie pak veřejné potvrzení jejich předního místa ve stavovské obci.

Zcela výjimečné postavení zaujímá poslední kvatern $\mathrm{M}$, v němž již přestala být dodržována tradiční pravidla skladebného schématu a majestáty byly intabulovány odděleně formou samostatných vkladů (detailněji viz níže).

Plně v souladu se svým názvem mohly být kvaterny majestátů využity rovněž k intabulaci řady dalších privilegií soukromoprávní povahy nebo písemností veřejným charakterem zemského či dokonce celostátního významu. Nejvíce takových vkladů bylo vloženo do kvaternu A, ovšem i v dalších kvaternech je jejich přítomnost patrná. Dotyčné vklady často informovaly o změnách na postech nejvyšších moravských a výjimečně i českých zemských úředníků, ${ }^{29}$ o změnách na postech představených moravských duchovních instituci $^{30}$ či v záležitostech míst a hlasů zemských prelátů na zemském sněmu, ${ }^{31}$ o titulárních povýšeních moravských či českých dominií, ${ }^{32}$ o normativech dotýkajících se vedení zemských desk, ${ }^{33}$ o potvrzeních platnosti všech majestátů vydaných regentkou Mariî Magdalenou Falcko-Neuburskou po dobu pobytu císaře Karla VI. ve Španělsku v druhé polovině roku $1711^{34}$ apod. Poměrně rozsáhlý a velmi zajímavý soubor představují vklady statut brněnského ústavu šlechtičen Panny Marie školské (tzv. Mariaschul) a jejich úprav a zřizování nových prebend z konce 18. století a první poloviny 19. století (1793, 1797, $1801,1806,1807,1841$ a 1845$).{ }^{35}$

inv. č. 66, fol. 123r-131v), Podstatský-Lichtenštejn 1762 (tamtéž, fol. 167v-176v).

29 Např. ustavení Kryštofa Pavla hraběte Lichtenštejna-Kastelkorna moravským zemským hejtmanem roku 1643 nebo potvrzení dědičné hodnosti českého nejvy̌šího hofmistra pro držitele majorátního panství Chlumec nad Cidlinou z rodiny Kinských roku 1743. MZA, A 3, inv. č. 59, fol. 7v-10r; inv. č. 64, fol. 445v-448; k Lichtenštejnovi-Kastelkornovi také viz Konečný, M. (ed.): Kryštof Pavel z Liechtensteinu-Castelkornu, s. 20.

30 Např. potvrzení volby P. Jana Nepomuka Středy novým proboštem křižovnického kláštera v Hradišti sv. Hypolita z Znojma roku 1766. MZA, A 3, inv. č. 67, fol. 18v-20v.

31 Např. pro zástupce řádu německých rytířu roku 1739. MZA, A 3, inv. č. 64, fol. 315r-317r.

32 Povýšení moravských majetků Gundakara z Lichtenštejna Moravský Krumlov a Uherský Ostroh na knížectví Liechtenstein roku 1633, MZA, A 3, inv. č. 59, fol. 54v-57v, vklad z roku 1648; Winkelbauer, Thomas: Fürst und Fürstendiener. Gundaker von Liechtenstein (1580-1658). Ein österreichischer Aristokrat des konfessionellen Zeitalters. Wien 1999, s. 338-353. Povýšení českého panství Zákupy na vévodství ve prospěch ve prospěch Napoleona Františka Josefa Karla Bonaparta, zvaného Orlík, syna bývalého francouzského císaře Napoleona I. a vnuka císaře Ferdinanda I. roku 1818, MZA, A 3, inv. č. 70, fol. 12v-13v; Tulard, Jean: Napoleon II. Legendy a skutečnost. Praha 1994, s. 71-74; Holler, Gerd: Orlik, vévoda Zákupský. Napoleonův syn. Praha 1999, s. 111-113.

33 Zejm. desková instrukce z roku 1642 a její upřesnění Josefem I. z roku 1708. MZA, A 3, inv. č. 62, fol. 444v-460v; srov. NA, ČDK, inv. č. 1073, sg. VI-B-4, kart. 880.

34 MZA, A 3, inv. č. 62, fol. 305v-310v: vklad obsahuje také plnou moc, kterou Karel VI. udělil 20. 7. 1711 v Barceloně své matce $\mathrm{k}$ vládnutí po dobu jeho nepř́tomnosti v monarchii.

35 K ústavu viz Wodiczka, Peter: Geschichtliche Daten über das Brünner k. k. adelige Damenstift (Maria Schul) seit seiner Gründung und Entstehung bis an die Gegenwart. Brünn 1887 a Brodesser, Slavomír: Brněnský Palác šlechtičen v proměnách času. Vlastivědný věstník moravský 53, 2001, čís. 1, s. 80. 
Tab. 3: Obsahová skladba intabulací

\begin{tabular}{|c|c|c|c|c|c|c|c|}
\hline Kvatern & Čas. rozpětí & Habilitace & Juramentum & $\begin{array}{l}\text { Venia aeta- } \\
\text { tis }\end{array}$ & Privilegium & Jiné & Celkem \\
\hline$A(59)$ & $1642-1669$ & 123 & 1 & - & 24 & 16 & 164 \\
\hline B (60) & $1670-1686$ & 47 & 1 & 1 & 14 & 1 & 65 \\
\hline$C(61)$ & $1686-1701$ & 36 & - & 1 & 17 & 1 & 56 \\
\hline$D(62)$ & $1701-1717$ & 48 & - & 1 & 19 & - & 70 \\
\hline E (63) & $1717-1731$ & 43 & - & - & 21 & 2 & 66 \\
\hline \begin{tabular}{|l|} 
\\
\end{tabular} & $1732-1743$ & 38 & - & - & 10 & 5 & 53 \\
\hline G (65) & 1743-1755 & 45 & - & - & 8 & 3 & 56 \\
\hline H (66) & $1755-1766$ & 34 & - & - & 5 & 2 & 41 \\
\hline$I(67)$ & $1766-1773$ & 33 & - & - & 11 & 1 & 45 \\
\hline K (68) & 1773-1785 & 43 & - & - & 8 & 2 & 53 \\
\hline$L(69)$ & 1786-1815 & 93 & - & - & 6 & 8 & 110 \\
\hline M (70) & 1816-1852 & $53 *$ & - & - & 35 & 5 & 93 \\
\hline
\end{tabular}

* = Počet intabulací registrujících absolvovanou habilitaci v zemi je ve skutečnosti vyšší, nebot (jak bude ještě níže vysvětleno) značné množství habilitačních řízení bylo rozděleno do dvou separátních vkladů (privilegium, revers k zemi).

\section{Písemnosti habilitace v zemi a vývoj skladebného schématu intabulací}

V kvaternech majestátů a analogicky i kvaternech slibů věrnosti byl od jejich počátků užíván do jisté míry specifický úzus intabulace př́íslušných písemných dokumentů, který nezpochybnitelně dokládal řádné podstoupení všech nezbytných dílčích kroků. V průběhu existence kvaternů majestátů můžeme rozlišit tři základní období, jež jsou pro užívanou intabulační praxi charakteristická.

a) Obdobi od založeni kvaternů do počátku 18. století

$\mathrm{Z}$ administrativního hlediska byl vlastní habilitační proces definován naprosto přesně již díky příslušným nařízením OZZ a DaN, deskové instrukce z let 1642 a 1708 se k němu již nijak nevyjadřovaly. $\mathrm{V}$ habilitačním procesu tak byla v tomto popisovaném období stabilně zaangažována trojice zeměpanských úřadů, a to v následující komunikační linii: I. česká dvorská kancelár̆ $\rightarrow$ II. tribunál (úřad zemského hejtmanství) $\rightarrow$ III. úřad zemských desk. Česká dvorská kancelář vyhotovila o poskytnuté panovnické milosti (nobilitaci, inkolátu, povolení vykonat slib věrnosti u tribunálu, udělení plnoletosti) písemnou intimaci (intimát), ${ }^{36}$ kterou zaslala moravskému tribunálu. Tuto panovnickou intimaci pak úředníci tribunálu opatřili vlastní doprovodnou intimací a obě písemnosti zaslali deskovému úřadu. Pokud na udělení inkolátu bezprostředně nenavazovaly další kroky vedoucí k úspěšné habilitaci v zemi (vykonání osobního slibu věrnosti, odevzdání reversu k zemi), byly intimace české kanceláře i tribunální intimace založeny do zemské registratury. ${ }^{37}$

$36 \mathrm{~K}$ pojmu intimát, popř. insinuát viz kap. 4, oddíl b v této studii.

37 Uváděný proces nezbytné úřední publikace vydaného panovnického privilegia na úrovni všech českých 
Pokud uchazeč o přijetí mezi zemské stavy v návaznosti zisk inkolátu řádně vykonal předepsaný osobní slib věrnosti, at již při české dvorské kanceláři nebo s pomocí panovnického povolení u moravského tribunálu, byl o této skutečnosti deskový úrad zpraven bud' v rámci samostatných kancelářských a tribunálních intimací, nebo - jak bylo obvyklé do počátku 70. let 17. století - v intimacích současně hovořících o udělení inkolátu. Samostatné písemnosti dokládající vykonání slibu věrnosti se v kvaternech majestátů hojně objevují až do přelomu 17. a 18. století, a tedy i po roce 1671, kdy byly pro jejich ucelenou registraci zřízeny zvláštní deskové kvaterny slibů věrnosti. Když nakonec tribunální úředníci obdrželi revers k zemi, taktéž jej opatřili doprovodnou intimací adresovanou deskovému úřadu, která současně sloužila jako tribunální př́ikaz k provedení intabulace. Vzniklý aktový materiál byl poté založen do zemské registratury. ${ }^{38}$ Panovnické intimace o zisku majestátu ovšem samy o sobě k intabulaci nestačily a musely být doprovázeny opisem vlastního panovnického privilegia. Dodáním jejich originálů byli povinni jejich vlastníci. Jelikož šlo o soukromé vlastnictví, byly tyto písemnosti po intabulaci deskovým úřadem opět vráceny svému majiteli, tj. vkladateli. Na rozdíl od majestátů byly reversy k zemi adresovány tribunálu, a proto byly - jistě vzhledem ke svému obsahovému významu i vyhotovení ve formě listiny - po ukončení intabulačního řízení uloženy ve zvláštní sbírce zemské registratury. ${ }^{39}$ Jednotlivé vklady jako celky byly odděleny záhlavím obsahujícím především dataci provedení intabulace, dílčí písemnosti byly uvozeny svými vlastními záhlavními regesty.

V průběhu vedení prvních tří kvaternů (A-C, vedeny 1642-1699) bylo pozvolna vyprofilováno univerzální schéma vnitřní struktury jednotlivých vkladů, které do značné míry zohledňovalo chronologii vydávaných písemností a dokumentovalo tak celý proces společenského vzestupu jednotlivce od jeho nobilitace až po přijetí mezi zemské stavy. $\mathrm{S}$ převládající přítomností tohoto schématu se setkáme až v kvaternech B (1670-1686) a C (1686-1701), jeho definitivní vítězství pozorujeme až od počátku 18. století. V prvních třech kvaternech se tak můžeme setkat $\mathrm{s}$ vklady, v nichž byl například revers k zemi v rozporu s chronologií i věcnou posloupností habilitace $\mathrm{v}$ zemi zařazen doprostřed souboru intabulovaných listin. Nijak výjimečná nebyla ani absence některých písemností, často majestátů nebo panovnických intimací. I přes tuto nedokonalost byly v rámci vnitřní skladby vkladů jednotlivé intabulované písemnosti již od konce 40. let 17. století stabilně seskupovány do tematických kategorií, které zobrazovaly podstoupené kroky vedoucí k nabytí moravské stavovské příslušnosti. Ve své nejširší podobě, tedy při stavovském vzestupu nobilitovaného nešlechtice, byly v zásadě čtyři: I. nobilitace, II. inkolát, III. slib věrnosti, IV. revers k zemi. V rámci prvních dvou kategorií byla doslovně opsána nejprve tribunální intimace, poté panovnická intimace a nakonec př́ílušná panovnická listina; v př́ípadě intabulace dokladů o vykonání juramenta fidelitatis, tedy do přelomu

zemí byl obligatorně podstupován vždy, když došlo k vydání majestátu. Panovnické intimace byly kanceláří standardně vyhotovovány již v rámci nobilitačního nebo inkolátního řízení. Brňovják, Jiří: Nobilitačni spisy České dvorské kanceláre z období vlády císaře Karla VI. (1712-1740). Sborník archivních prací 56, 2006, č. 1, s. 100-101. Příslušné spisy stavovské registratury se dnes nacházejí v MZA ve fondu A 12 Akta šlechtická. Srov. Kocman, A. a kol.: Průvodce po Státním archivu v Brně. Brno 1954, s. 189-190. 
17. a 18. století, to byla nejprve tribunální intimace a poté panovnická intimace; odevzdání reversu k zemi dokládala tribunální intimace a opis reversu.

Poměrně komplikovaná intabulační praxe byla dána novým způsobem úředního jednání, který byl v českém prostředí prosazen po porážce stavovského povstání a v mnohém „kodifikován“ již v ustanoveních Obnovených zřízení zemských. Původní tradiční české právo, které bylo založeno na uplatňování nálezů, bylo v jednáních zemského soudu nahrazeno německým (ř́ršským) právem, jež akcentovalo písemné projednávání opřené o kodifikované právní normy. Zemské desky byly podle instrukce z roku 1642 otevřeny stále, nejen během zasedání zemského soudu. Deskový úřad jako plně zeměpanská instituce díky tomu získal pevně dané úřední hodiny. Z intabulační praxe bylo odstraněno tradiční osobní přiznání vkladatele (resp. prostřednictvím zplnomocněnce), jehož místo zaujala písemná úřední komunikace. V zájmu zachování právní nezpochybnitelnosti deskových vkladů se ukázalo jako nezbytné intabulovat všechny relevantní písemnosti in extenso. Zemské desky se tak prakticky změnily v kopiáře listin a podání dokládající dané právní pořízení. ${ }^{40}$

$\mathrm{V}$ popsaném kontextu představuje v kvaternech majestátů jeden z posledních „antimodernizačních“ reliktů dřívější předbělohorské intabulační praxe zaznamenávání přítomnosti královských relátorů. Jak zjistil J. Kocurek, tyto záznamy se objevují pouze v období let 1642-1650 a nikoliv ve všech vkladech, jež byly zakončeny opisem reversu k zemi. Úkolem relátorů vysílaných k úřadu zemských desk tribunálem bylo doručit všechny příslušné písemnosti (je otázkou, zda již včetně majestátů získaných od jejich majitelů) a formálně požádat o jejich intabulaci. Tuto předbělohorskou zvyklost přenesla do pobělohorského období desková instrukce z roku 1642, která výslovně vyžadovala uvedení jmen přítomných relátorů. Ačkoliv mělo jít o normu, je jistě více než zajímavé, že po osmi letech vedení prvního kvaternu bylo od uvádění relátorů v praxi natrvalo upuštěno. Relátoři byli vybíráni na základě rozhodnutí tribunálu, jenž za tímto účelem vyhotovil zvláštní intimaci adresovanou deskovému úřadu, kterou však již deskový úřad do dané intabulace nezařadil; snad proto, že přítomnost královských relátorů byla do kvaternů majestátů následně sama písemně zaznamenána. Jedním z relátorů byl zpravidla vybírán královský prokurátor, tribunální kancléř nebo posléze často znojemský krajský hejtman, druhým pak některý z přísedících tribunálu. ${ }^{41}$

\section{b) Obdobi od počátku 18. století do 80. let téhož století}

Již první zápisy do kvaternu D, jenž byl veden od roku 1701, ukazují, že na počátku 18. století došlo k definitivnímu dotvoření intabulačního úzu, který ve své stabilní podobě

40 Demuth, K. J.: Geschichte, s. 190-202. Dále srov. Burdová, P.: Desky zemské, s. 347-350 a 352-355; Kůrka, Pavel: Desky zemské. In: Akademická encyklopedie českých dějin, 4. D-G. Praha 2015, s. 132-133. K předbělohorské intabulační praxi s přesahy do 40 . let 17 . století srov. obsáhlé úvody v Matějek, František: Moravské zemské desky 1567-1642, III. Kraj olomoucký. Praha 1953, s. XL-XCII a Rohlík, Miloslav: Moravské zemské desky 1567-1641, III. Kraj brněnský. Praha 1957, s. XXVI-XLIII.

41 Kocurek, J.: Kvatern, s. 56-60. Kocurek odkazuje na několik dochovaných originálů tribunálních intimací ve spisech stavovské registratury (dnes fond A12). Zánik záznamů o relátorech (poslech) lze dát do souvislosti s celkovým vymizením potřeby relátorů v pobělohorském období, jak o ní hovoří $\mathrm{F}$. Matějek (Moravské zemské desky, s. LXIV). Podle něj totiž vklad nařizoval panovník ve své listině, v př́ípadě habilitace v zemi tak činil již ve své intimaci; formálně vklad pak písemně nařizoval moravský tribunál. 
setrval až do závěru století. K jeho narušení docházelo jen ve velmi omezené míře, přičemž těmto př́ípadům nelze $\mathrm{v}$ žádném př́ípadě přisuzovat jakýkoliv antisystémový charakter - spíše se lze domnívat, že byly způsobeny nedůsledností úředníků či písařu deskového úřadu. Vklad, který formou opisů př́ílušných dokumentů zobrazoval podstoupení všech právních nezbytností při habilitaci osoby nešlechtického původu, byl tradičně strukturován následujícím zpo̊sobem:

datované záhlavi;

nobilitace: intimace zemské vlády (do 1749 tribunál, do 1763 reprezentace a komora, poté gubernium) + panovnická intimace (do 1763: panovník osobně informuje o poskytnuté milosti), resp. dvorská intimace (od 1763: česká a rakouská spojená dvorská kancelář informuje o poskytnutí panovnické milosti) + panovnická listina (majestát);

inkolát: intimace zemské vlády + panovnická/dvorská intimace + panovnická listina (majestát);

slib věrnosti panovnikovi: intimace zemské vlády + panovnická/dvorská intimace;

revers $k$ zemi: intimace zemské vlády včetně příkazu $\mathrm{k}$ intabulaci + revers.

Jelikož tíhu registrace skládání slibů věrnosti plně převzala samostatná řada kvaternů slibů věrnosti, z kvaternů majestátů v podstatě vymizely opisy písemností, které by se primárně věnovaly této povinnosti. O složení slibu věrnosti a jeho konkrétních okolnostech se pak dozvídáme ze zmínek v intimacích zemské vlády o převzetí reversu k zemi a jeho odeslání k intabulaci, stejně jako v úvodech reversů samotných.

Již zmíněná trojice zaangažovaných dvorských a zemských úřadů se na habilitačním procesu a následné intabulaci patřičných písemných dokladů podílela až do konce 40. let 18. století. Když byly roku 1749 administrativně sloučeny historické české a rakouské země v jeden univerzální celek dědičných zemí, veškeré kompetence bývalé české dvorské kanceláře včetně agendy nobilitační, inkolátní a z části habilitační (skládání slibů věrnosti) převzalo nově ustanovené vídeňské Directorium in publicis et cameralibus. Reforma se na stávající intabulační praxi ale v zásadě nijak dále neprojevila, stejně jako nahrazení Direktoria českou a rakouskou spojenou dvorskou kanceláŕí roku 1761; uvedené nejvyšší dvorské úřady byly nadále povinny dodávat zemské vládě příslušné intimace. Obdobně neovlivnila stávající intabulační praxi ani tereziánská reorganizace nejvyšších zemských úřadů, která se na Moravě uskutečnila v letech 1748-1749. Proměna dřívějších zemských vlád v královské reprezentace a komory byla dostatečně zřetelně zachycena v dílčích záhlavních regestech intabulovaných písemností.

c) Obdobi od 80. let 18. stoleti do poloviny 19. století

Takřka stoleté období respektování ustálené intabulační praxe bylo poprvé vážněji dotčeno až reformami Josefa II., k nimž v administrativní a soudní sféře došlo v první polovině 80 . let 18. století. Za určitou předzvěst nadcházejících proměn lze chápat zrušení povinnosti juramenta fidelitatis roku 1781, díky čemuž ztratilo vedení kvaternů slibů věrnosti své opodstatnění. ${ }^{42}$ Správní reforma z let 1782-1783, jejímž výsledkem bylo spojení moravských a rakousko-slezských zeměpanských úřadů v jeden celek, sice ne-

42 Roku 1783 zanikly i české kvaterny majestátů, srov. Burdová, P.: Desky zemské (1993), s. 362, 398-399, 425, 429 . 
zpochybnila základy užívané intabulační praxe, ale výrazně zasáhla do kompetencí zainteresovaných úřadi̊. Př́jemcem dvorských intimací se stalo moravskoslezské zemské gubernium, které však oproti dřívější praxi již dále nekomunikovalo s deskovým úřadem, nýbrž moravskoslezským zemským právem: v průběhu josefinské soudní reformy deskový úřad totiž na základě dvorského dekretu z 24. března 1783 ztratil svou dosavadní samostatnou pozici a učinil z něj pouhé oddělení moravskoslezského zemského práva, tzv. záznamní úřad (Vormerksamt). ${ }^{43}$ Tyto změny se projevily v adresách guberniálních intimací intabulovaných od roku 1784, jež tak byly nyní zasílány „ad intabulandum “ zemskému právu. Ještě téhož roku začala být pod záhlaví vkladů doplňována informace, že intabulace byla provedena na př́kaz moravskoslezského zemského práva. Od roku 1790 se stala přímou součástí ústředního záhlavního regestu formule „So beschehen auf königl. Landrechtliche Verordnung den [datum]. “

V následujícím období do poloviny 90. let 18. století došlo také k zásadnímu přeorganizování vedení českých i moravských zemských desk, jejichž výsledkem bylo definitivní oddělení stavovské a majestátní agendy od záležitostí vlastního deskového majetku a veškeré manipulace s ním. Moravský stavovský zemský výbor převzal již roku 1781 do své péče sněmovní památky, roku 1783 pak byly do registratury moravskoslezského zemského práva převedeny soudní, trhové, dlužní a odhadní kvaterny. Další zásadní kompetenční změnu v intabulačních záležitostech předznamenalo nařízení dvorského dekretu z 1. prosince 1789, podle něhož byly kvaterny majestátů převzaty moravským stavovským zemským výborem. Roku 1794 byla do péče zemské výboru převedena také zemská registratura (archiv). ${ }^{44}$ Ovšem ještě po následující čtyři roky podléhala vlastní intabulační agenda moravskoslezskému zemskému právu, které - jak dokládají záhlaví vkladů té doby - intabulaci nařizovalo. Až od počátku roku 1793 tyto regesty informují o provedení intabulace na základě př́kazu stavovského zemského výboru. Od druhé poloviny roku 1805 (trvale od roku 1815) bylo navíc zaznamenáváno jednací číslo, pod kterým bylo rozhodnutí stavovského zemského výboru vedeno. Aktový materiál z první poloviny 19. století dokládá, že vlastní intabulaci měl na starosti stavovský registrátor a expeditor (Landschaftsregistrator und Expeditor), jemuž zemský výbor adresoval své intimace s intabulačním příkazem. Stavovský registrátor byl stavovským zemským výborem

43 Reforma obdobně zasáhla také české zemské desky, srov. tamtéž, s. 348-350.

44 Demuth, K. J.: Geschichte, s. 241-249; Bretholtz, Berchtold: Morauský zemský archiv. Jeho dějiny a jeho sbírky. Brno 1908, s. 6; Kocman, A. a kol.: Pri̊vodce, s. 170; Burdová, P.: Desky zemské (1993), s. 351-352, 386-388, 393-395 a 401; Sedláček, Pavel: Zemské desky v Čechách od konce 18. století. In: Z archivních depozitářů. Pavle Burdové k 70. narozeninám. Praha 1998 s. 90-91; Kůrka, P.: Desky, s. 133. Od poloviny 80. let probíhající josefinská reorganizace moravských i českých zemských desk byla dokončena na základě patentu z 22. dubna 1794 a deskové instrukce z 5. července 1796, kdy byly pro majetkovou agendu po dolnorakouském vzoru vytvořeny hlavní pozemkové knihy, jež abecedně registrovaly veškerý dominikální majetek (v př́ípadě Moravy s výjimkou olomouckých lén). Důsledkem bylo zavedení tří řad českých zemských desk: menších, větších a stavovských, přičemž do poslední kategorie byly zařazeny kvaterny registrující šlechtické a stavovské záležitosti včetně habilitace v zemi, sněmovních usnesení či propůjčování zemských úřadů (stavovské desky byly roku 1795 formálně, nikoliv reálně předány představitelům českých stavů); na Moravě bylo v zásadě ponecháno stávající vedení ve dvou řadách, tj. vlastních zemských desk registrujících především majetkové záležitosti a do stavovských rukopisů, jak to ostatně nařizovala již instrukce z roku 1642. 
také pověřován založením intabulačních písemností do zemské registratury, resp. archivu (Landesarchiv). Stavovský zemský výbor taktéž zpětně informoval moravskoslezské zemské právo o uskutečněné intabulaci - činil tak jistě z toho důvodu, aby tuto informaci mohl nakonec zaregistrovat i záznamní úřad zemského práva, tj. vlastní historický deskový úřad. ${ }^{45}$

Na počátku roku 1783 si v rámci vnitřní struktury jednotlivých vkladů můžeme poprvé povšimnout absence dvorských intimací, které potvrzovaly zemským úřadům vydání panovnického privilegia (šlechtický titul, inkolát). Od počátku kvaternu L (od 1786) pak již dvorské intimace víceméně absentují stabilně, a to až do ukončení vedení kvaternů majestátů v 50. letech 19. století. Neznamenalo to však, že by dvorská kancelář upustila od jejich produkce. O jejich existenci se dozvídáme v textech guberniálních intimací, které se na ně a na jejich obsah tradičně odvolávají, přičemž neopomíjely uvést vedle data jejich vydání rovněž datum přijetí u gubernia. Jejich originály jsou uloženy v příslušných spisech stavovské registratury, koncepty v nobilitačních a inkolátních spisech dvorské kanceláře. ${ }^{46}$ Nakonec od roku 1790 moravskoslezské zemské právo a následně moravský stavovský zemský výbor upustily i od intabulování guberniálních intimací, čímž se struktura deskových vkladů zredukovala v zásadě jen na opisy originálů majestátů a reversů k zemi. Guberniální intimace se pak objevují pouze výjimečně a slouží jako oficiální ověřený doklad o vydaném panovnickém privilegiu, které uchazeč o intabulaci nebyl schopen v originálu dodat a jež bylo nezbytné $\mathrm{k}$ doložení jeho šlechtictví či př́íslušnosti mezi inkolované obyvatele českého státu. Lze se teoreticky domnívat, že k tak výraznému zeštíhlení intabulací došlo právě v souvislosti s převedením intabulační agendy na moravskoslezské zemské právo a zejména pak na moravský stavovský zemský výbor. Úředníci druhé jmenované instituce rozhodně nedisponovali dostatkem zkušeností, a hlavně kapacity na vedení intabulací v tradičním extensivním duchu, který vyžadoval pečlivé doslovné opisování všech potřebných písemností (nutno dodat, že mnohé důležité informace se díky tomu v opisovaných písemnostech často opakovaly dvakrát či třikrát).

Ačkoliv v průběhu předposlední dekády 18. století byl zahájen zásadní proces obsahové redukce jednotlivých intabulací, dochovaný spisový materiál ze stavovské registratury z období po roce 1786 a vnitřní úřední knihy zemského výboru ukazují, že vlastní intabulační řízení bylo mnohem složitější, než jak jej zobrazují záznamy v kvaternech majestátů. Ve spisech se často setkáme se živou korespondencí, kterou zemský výbor vedl se zemským guberniem a zemským právem v záležitostech prověřování legální způsobilosti uchazečů o intabulaci, kteř́i byli povinni podstoupit habilitaci v zemi. Od 90. let byl navíc do procesu zaangažován i apelační soud, jenž kompetenčně stál mezi vídeňským Nejvyšším soudním místem a brněnským zemským právem (roli apelačního soudu bude nutné ještě detailněji prozkoumat). Stejně tak se ujímal zahájení celého intabulačního řízení

45 Srov. doklady v MZA, A 8 Zemská registratura, sg. E 2, kart. 382-395. Úředníci záznamního úřadu (deskového úřadu) moravskoslezského zemského práva si vedli vlastní vnitřní úřední knihy, viz A 3, inv. č. 48 a 597-602.

46 MZA, A 8, sg. E 2, kart. 382-395, šlechtické záležitosti z let 1786-1874. Pro předchozí období srov. spisy ve fondech A 12 Akta šlechtická a B 1 Gubernium, zde sg. S12; koncepty dvorských intimací viz Österreichisches Staatsarchiv, Allgemeines Verwaltungsarchiv, Adelsarchiv - Hofadelsakten. 
a aktivně vyzýval nehabilitované nové držitele či potenciální dědice uvolněných moravských deskových statků k vyřízení nezbytných habilitačních formalit. Tuto agendu aktový materiál před rokem 1786 neobsahuje. ${ }^{47}$

V kontextu proměn intabulační praxe, $\mathrm{k}$ nimž docházelo od konce 18. století, je nezbytné připomenout skutečnost, díky které se poslední kvatern majestátů (M, od 1816) zásadně liší od svých předchůdců: od poloviny 30. let 19. století se stalo takřka pravidlem, že jednotlivé písemnosti konkrétního habilitačního řízení již nebyly intabulovány v jednom souhrnném vkladu, nýbrž do několika separátních vkladů (nejčastěji dvou až tří) oddělených vlastním záhlavím, a to i přesto, že všechny tyto „dílčí “ vklady byly učiněny na základě jednoho rozhodnutí moravského stavovského zemského výboru. Na otázku, proč úředníci zemského výboru zvolili takto markantně netradiční a na první pohled nepř́liš logický postup, nedovoluje současný stav bádání odpovědět.

Záznamy do kvaternů majestátů byly stejně jako jakékoliv jiné intabulace patřičně zpoplatněny. Při vyměřování př́íslušných tax se deskový úřad mohl řídit taxovním řádem, který byl pro moravský tribunál a zemské desky vydán Ferdinandem III. 6. ř́jna 1640. Nejvyšší částky byli vkladatelé nuceni uhradit za intabulaci reversu: obyvatelé českého státu užívající knížecí, hraběcí nebo panský titul museli zaplatit 100 moravských zlatých nebo 116 zlatých (rýnských) 40 krejcarů, cizincům s analogickými tituly byla vyměřena dvojnásobná taxa, tedy ve výši 200 moravských zlatých nebo 233 zlatých 20 krejcarů. Tuzemcům rytiŕrského stavu bylo nařízeno zaplatit 50 moravských zlatých (58 zlatých 20 krejcarů), cizincům dvojnásobek, tj. 100 moravských zlatých nebo 116 zlatých 40 krejcarů. Za intabulaci opisů panovnických majestátů byli všichni intabulanti povinni zaplatit univerzální taxu 1 moravský zlatý 11 grešlí a 2 feniky nebo 1 zlatý 36 krejcarů a 1 denár; intabulace prohlášení zletilosti bylo vyčísleno ve stejné výši. Podle M. Talíre, jenž roku 1912 publikoval extrakt citovaného taxovního řádu, byly tyto taxy spojeny s intabulací reversu v rámci stavovského povýšení, vklad samotného reversu či majestátního listu vyšel výrazně levněji (11 zlatých 40 krejcarů, resp. 4 zlaté 40 krejcarů). Taxovní řád dále požadoval za intabulaci panovnických a tribunálních intimací příslušníkem vyšší šlechty 50 zlatých a prríslušníkem rytírského stavu 20 zlatých (podle Talíre 58 zlatých 20 krejcarů, resp. 29 zlatých 20 krejcarů). Původní taxa 100 zlatých za intabulaci nobilitačního privilegia se nakonec jevila i u vídeňského dvora jako příliš vysoká („allzu excessiv“), a proto Leopold I. nařídil reskriptem z roku 1704 její snížení na polovinu. Panovník své rozhodnutí doslovně zdůvodňoval těžkými časy. ${ }^{48}$ Další reálný vývoj intabulačních poplatků prozatím neznáme, připomenout lze pouze návrh taxovního řádu pro Moravu z roku 1749, který požadoval za intabulaci knížecí listiny 600 zlatých, hraběcí 150 zlatých, baronské 100 zlatých, rytířské 50 zlatých a (prosté) šlechtické 30 zlatých. Za intabulaci inkolátní listiny

47 MZA, A 8, sg. E 2, kart. 382-395. Pro předchozí období srov. spisy ve sbírkách MZA, A 12 Akta šlechtická a B 1 Gubernium, sg. S 12.

48 MZA, C 4 Tribunál - normalia, inv. č. 42, nedatovaný opis; D‘Elvert, Christian: Beiträge zur Geschichte der Rebellion, Reformation, des dreißigjährigen Krieges und der Neugestaltung Mährens in den siebzehnten Jahrhunderte. Schriften der historisch-statistischen Sektion der k. k. m. s. Gesellschaft zur Beförderung des Ackerbaues, der Natur- und Landeskunde, 16. Brünn 1867, s. 491 (vydání řádu datuje k 6. 12. 1640), 877; Demuth, K. J.: Geschichte, s. 188; Taliŕ, Matouš: K dějinám rakouského taxovnictví, 2. Část zvláštní. Praha 1912, s. 19; Kocurek, J.: Kvatern, s. 65-66. 
v hraběcím stavu předepisoval 75 zlatých, ve stavu svobodných pánů 50 zlatých a v rytîr ském stavu 25 zlatých. V zásadě podobné, jen trochu vyšší poplatky vyžadoval podle řádů z let 1750 a 1764 deskový úřad Českého království. ${ }^{49}$ Vybrané intabulační taxy pak byly podle všeobecné dobové zvyklosti rozpočteny mezi úředníky deskového úřadu: nejvyššímu zemskému komorníku, nejvyššímu zemskému sudímu a zemskému písaři. Příjmy na taxách, nejen z intabulací habilitací a panovnických majestátů, byly zaznamenávány do taxovního rejstříku, který byl při deskovém úřadu veden. Bohužel, do dnešních dní se dochoval pouze jeden jediný svazek, pojednávající o letech 1655-1662. ${ }^{50}$

\section{K diplomatice intabulovaných písemností}

Jak bylo několikrát zmíněno, v souvislosti s pobělohorskými změnami se stalo zvykem zaznamenávat patřičná právní jednání do kvaternů českých i moravských zemských desk opisováním všech př́íslušných písemností v jejich plném znění. Právě v kvaternech registrujících habilitaci v zemi se tato praxe projevila nejmarkantněji. Díky tomuto úzu mohly být vklady často velmi obsáhlé, v případě habilitace nobilitovaného nešlechtice bylo intabulováno v průměru osm písemností včetně rozsáhlých nobilitačních listin. Celková délka takových vkladů pak mohla zaujímat téměř dvě desítky folií. Doslovné přepisy intabulovaných písemností v mnohém kopírovaly jejich formální vyhotovení, včetně kaligraficky zvýrazněné intitulace a promulgace a iniciál prvních slov jednotlivých odstavců textu, umístění podpisů, kaligraficky ztvárněné mandační poznámky a spíše ojediněle také grafické označení umístění pečetí (L.S.). V 80. letech 18. století začala tato písemná kultura mírně upadat: písaři si již nedávali takovou práci s detaily, které opisovaný text co nejvíce připodobňovaly originálu, a nakonec v první polovině 19. století (kvatern M) rezignovali na jakoukoliv jinou zdobnost než tu, s níž zvýrazňovali záhlaví vkladů a první řádky intabulovaných písemností. Jelikož v předcházející kapitole bylo na intabulované písemnosti nahlíženo především z pohledu genetické diplomatiky, tj. podle jejich funkční pozice v systému dobové úřední komunikace a jej reflektující podoby intabulačního skladebného schématu, v následujících odstavcích použiji pohled příslušný syntetické diplomatice, a proto se zaměřím na poznámky dotýkající se klasifikace intabulovaných písemností podle tradičně užívaných diplomatických kategorií. Současně se pozastavím také u vybraných vnějších a vnitřních diplomatických znaků popisovaných písemností. ${ }^{51}$

49 NA, ČDK, inv. č. 1049, sg. V-C-8, kart. 823; Talî́, M.: K dějinám, 2, s. 19.

50 D'Elvert, Christian: Zur oesterreichischen Finanz-Geschichte mit besonderer Rücksicht auf die böhmischen Länder. Schriften der historisch-statistischen Section 25. Brünn 1881, s. 339, srov. také rozpisy v NA, ČDK, inv. č. 1073, sg. VI-B-4, kart. 880. Taxovní rejstř́ik moravského deskového úřadu viz MZA, A 3, inv. č. 672.

51 Srov. př́slušné kapitoly v Stloukal, Karel: Česká kancelár dvorská 1599-1608. Pokus z moderní diplomatiky. Praha 1931; Meisner, Heinrich Otto: Aktenkunde. Ein Handbuch für Archivbenutzer mit besonderer Berücksichtigung Brandenburg-Preußens, vom 16. Jahrhundert bis 1918. Berlin 1935; Meisner, Heinrich Otto: Archivalienkunde vom 16. Jahrhundert bis 1918. Leipzig 1950; Šebánek, Jindřich - Húščava, Alexander - Fiala, Zdeněk a kol.: Československá diplomatika, I. Praha 1965, passim; Kloosterhuis, Jürgen: Urkunden und Aktenlehre der Neuzeit. Ein hilfswissenschaftliches Kompendium. Archiv für Diplomatik 45, 1999, s. 465-563; Hlaváček, Ivan: Diplomatika. In: Hlaváček, Ivan - Kašpar, Jaroslav - Nový, Rostislav: Vademecum 


\section{a) Nobilitačni a inkolátni listiny}

Na prvním místě naprosté většiny vkladů do kvaternů majestátů se nacházely písemnosti věnované udělení některého z dobových šlechtických titulů, minimálně však rytířského (s výjimkou kvaternu A), a to včetně vlastní panovnické listiny. Většinu intabulovaných listin lze označit do počátku 19. století za bohemikální, tj. do roku 1752 vydávané s výslovnou platností pro české země, po tomto datu pro celé dědičné země - stalo se tak v souvislosti se vznikem jednotné šlechtické titulatury dědičných zemí, jenž se zpožděním reagoval na administrativní reformu z roku 1749. Listiny tak byly expedovány do roku 1749 českou dvorskou kanceláří, poté Direktoriem a jeho dalšími dvorskými nástupci. Od druhého desetiletí 19. století byly listiny vydávány z moci nově ustavené rakouské císařské hodnosti (1804) a v nich udílené tituly byly považovány za součást šlechtické titulatury Rakouského císařství. ${ }^{52} \mathrm{~K}$ intabulacím šlechtických privilegií vydaných z jiné panovnické moci tak docházelo jen velmi zřídka: nejčastěji to byly listiny ř́ísské, po jednom případě nobilitace španělská a nobilitace haličská. ${ }^{53} \mathrm{~V}$ kvaternech majestátů se rovněž setkáme s 12 opisy českých konfirmací říšských privilegií, které svým př́ijemcům zajištovaly právní nostrifikaci jejich ř́̌šských titulů na území českého státu.

U diplomatické stránky intabulovaných nobilitačních listin se vzhledem k pozornosti, kterou badatelé $\mathrm{v}$ poslední době této problematice věnovali, stručně pozastavíme jen u několika vybraných aspektů. ${ }^{54}$ Dispozitivní (deklarativní) charakter těchto panovnických listin, produkovaných takřka výhradně panovnickou dvorskou kanceláří, a jejich účel se přirozeně promítal do jejich formální podoby. Slavnostně vypravené privilegium - tedy diplom či majestát, slovy moderní terminologie - bylo zpečetěno adekvátní panovnickou pečetí, podepsáno panovníkem a kontrasignováno představiteli kanceláře a současně i ve své nejstandardnější podobě náležitě vyzdobeno. V intabulační praxi byly tyto listiny v záhlavních regestech obecně nazývány diplomy (něm.: „Ihrer Kayser- und Königl. Mayett. Diploma“, „Kaiser. und. Königlich. Diploma“), v několika málo českých vkladech v prvních třech kvaternech nejprve jako „Majestát Jeho Milosti Cýsařske“, a posléze jako „jeho Císařské a Král. Milosti Diploma“.${ }^{55}$ Až na výjimky se jednalo o listiny vydané

pomocných věd historických. 2002, s. 198, 206-207; Hochedlinger, Michael. Aktenkunde. Urkunden- und Aktenlehre der Neuzeit. Wien - München 2009.

52 Brňovják, Jiří: Nobilitace a nobilitační politika v českých zemích v obdobi vlády Karla VI. a Marie Terezie. In: Pre blaho nášho l'udu, všetkých našich královstiev a provincii. Reformná politika Márie Terézie a jej pokus o modernizáciu Uhorska. I. Kušniráková a kol. Bratislava 2017, s. 43-45.

53 MZA, A 3, inv. č. M, fol. 85r-87v: panský stav Království haličského a lodoměřského pro olomouckého kanovníka Johanna von Konopka, 1791; MZA, A 3, inv. č. M, fol. 44v-47r: šlechtický stav pro Jeana de la Fontaine de Harnoncourt 1678 (Brusel, vydavatele španělský král Karel II.).

54 Zejm. Brňovják, J.: Nobilitačni spisy, s. 69-111 (na př́ikladu konceptů české dvorské kanceláře); týž: Šlechticem, s. 159-167; Krejčík, Tomáš: $K$ diplomatice nobilitačních a erbovnich listin v novověku. In: Nobilitace ve světle písemných pramenů. J. Brňovják a kol. Ostrava 2009, s. 13-35. K předchozím obdobím kontextuálně srov. Fiala, Michal: Tři studie k české renesančni heraldice (Znaky měštanů Starého Města pražského v letech 1526-1618 ve světle salbuchů). Heraldická ročenka 20, 1993, s. 3-32 a Maier, Daniel: Überlegungen zum Formular einiger Wappenbriefe der Reichskanzlei (1338-1500). Mitteilungen des Instituts für Österreichische Geschichtsforschung 126, 2018, s. 34-52.

55 Listiny ve svých formulářích samy sebe označovaly za „list“, „Brief“ či „Diploma“. V souladu s právním ujednáním byly tyto termíny často doplňovány o patřičná adjektiva: „list erbovni“, „Wappenbrief“, na základě 
v období po porážce stavovského povstání, kdy se stalo pravidlem vyhotovovat čistopisy listin formou libelů. Listiny si udržovaly svůj kvartový formát i způsob vazby do sametem potažených papírových desek. Ke zpečetění byla užívána tradiční velká česká znaková pečet (Sigillum Bohemiae) zavedená Ferdinandem I., výrazněji inovovaná až po nástupu Karla VI., resp. jeho dcery Marie Terezie na český trůn. Roku 1753 byla nahrazena novou pečetí pro dědičné země, která sama ustoupila roku 1804 pečeti Rakouského císařství. ${ }^{56}$ Dalšími ověřovacími prvky byly vlastnoruční podpisy panovníka jako vydavatele, nejvyššího kancléře a sekretáře. Struktura formuláře odpovídala zažitým pravidlům, jež byla používána již od středověkých počátků nobilitačních a erbovních listin. Mezi nejvýraznější prvky patřila mimořádně kaligraficky ztvárněná velká panovnická intitulace vydavatele a erbovní miniatura, profesionálně vymalovaná na celou jednu strana folia v textu, který hovořil o uděleném (resp. potvrzeném či polepšeném) erbu a jeho blasonu. Nobilitační listiny si uchovávaly svou tradiční květnatou a komplikovaně působící formulářovou strukturu až do 20. let 19. století. Poté došlo k jejímu zásadnímu zjednodušení, což lze klást chronologicky i věcně do souvislosti se zavedením jednotné šlechty Rakouského císařství. Výrazně byl zkrácen protokol, bohaté a mnohdy se opakující dispoziční formule vlastního textu listiny a rovněž eschatokol (s výjimkou formulací ohlašujících podpisy dvorských úředníků).

Fixovanou písemnou formu jednofoliové listiny (charty) získal díky pobělohorským ustanovením panovnický souhlas (Consens) k zakoupení a disponování deskových statků v českých zemích, od cca poloviny 17. století univerzálně zvaný inkolátem. Počátky inkolátních listin bychom našli již krátce po porážce stavovského povstání roku 1620, kdy se panovník snažil touto majestátní formou zajistit právoplatné nabytí uvolněných statků cizinci, kteří v císařských službách přicházeli do českých zemí. Inkolátní listiny byly obdobně jako jiné majestátní písemnosti opatřeny českou velkou znakovou pečetí a podpisy panovníka a odpovědných představitelů české kanceláře. V německé intabulační terminologii proto byly stejně jako listiny nobilitační označovány za císařský a královský diplom („Ihrer Kay. und König. Diploma“, od konce 18. století pak pouze jako „Incolats-Diploma“), stejný termín byl použit také v ojedinělých českých vkladech v prvních dvou kvaternech („Diploma Iuris Incolatus“). Od nobilitačních listin se ale odlišovaly menší mírou slavnostního zpracování: především užitím střední panovnické titulatury a sníženou

konkrétního uděleného šlechtického stavu jako „Nobilitierungsdiploma“, „Adelsbrief“, „Rittersbrief“ apod., s odkazem na osobu panovníka jako vydavatele a slavnostní formu vyhotovení pak např. jako „list Náš“, „majestát", „Majestätsbrief“ či „Unser (kaiserlicher) Brief“. Moderní diplomatika používá pojmy listina, diplom či privilegium, k nimž připojuje potřebné adjektivum (erbovni, nobilitačni), popř. pojem majestát; v němčině jsou nejčastěji použivány termíny (Wappen-, Nobilitierungs-) Urkunde nebo Brief či Standeserhebungsurkunde, v obecné rovině či v kontextu kancelářské praxe a popisu vyhotovení listiny bývá použit pojem Diplom. K užívané historické i moderní terminologii zejm. Stloukal, K.: Česká kancelár̆, s. 69-74; Meisner, H. O.: Aktenkunde, s. 4-13; Meisner, H. O.: Archivalienkunde, s. 16-17; Kloosterhuis, J.: Urkunden, s. 465-563; Hlaváček, I.: Diplomatika, s. 198, 206-207; Rameš, Václav: Slownik pro historiky a návštěuniḱy archivui. Praha 2005, s. 58, 139, 144, 219-220; Hochedlinger, M.: Aktenkunde, s. 24-29, 177.

56 Brňovják, Jiří: Velká znaková pečet Marie Terezie - zánik samostatné české panovnické sfragistiky. In: Néméthová, Sylvia (ed.): Mária Terézia a jej doba vo svetle pomocných vied historických. Zborník príspevkov z vedeckej konferencie s medzinárodnou účastou pri príležitosti 300. výročia narodenia Márie Terézie. Bratislava 2017, s. 38-63. 
mírou kaligrafického ztvárnění textu. Méně obsáhlý formulář (zejména v naraci) umožnil, aby si inkolátní listiny uchovaly formu charty až do konce své existence v polovině 19. století. Inkolátní listiny ve formě libelu byly vyhotovovány patrně jen velmi vzácně a zřejmě jen na výslovné přání příjemce, který byl za honosnější vzezření listiny ochoten patřičně připlatit. ${ }^{57}$

Originály nobilitačních a inkolátních listin, pokud se dochovaly, se staly součástí nejrůznějších archivních fondů a sbírek v řadách českých, slovenských, rakouských a částečně i polských archivů či muzeí. Setkáme se s nimi nejčastěji ve šlechtických rodinných archivech nebo pozůstalostech. Ale takto dochované listiny tvoří pouhý zlomek z celkového množství listin vyprodukovaných českou dvorskou kanceláří a jejími nástupci až do zániku habsburské monarchie. ${ }^{58} \mathrm{~V}$ případě intabulace byla deskovým, resp. posléze stavovským registrátorem zaznamenána na poslední prázdné folio listiny datovaná poznámka (dorzální přípisek, indorsát) o provedení intabulace včetně uvedení příslušného kvaternu a folií.

U naprosté většiny intabulovaných nobilitačních listin zůstalo prázdné místo pro vymalování uděleného erbu, tak jak byl obsažen v originále listiny. V 83 případech byly listiny na patřičném místě doplněny barevným vyobrazením v blasonu popisovaném erbu. Vymalování erbu, které vyžadovalo služeb zkušeného erbovního malíre, nepochybně nebylo standardní součástí intabulací listin, ale dělo se jen na zvláštní přání vkladatele a jistě bylo také náležitě zpoplatněno, na což většina vkladatelů pragmaticky rezignovala. ${ }^{59}$ Absence této položky v taxovním rejstříku z roku 1642 napovídá, že k vymalování erbu a stanovení konkrétní ceny patrně docházelo na základě individuální dohody vkladatele $\mathrm{s}$ malířem. $\mathrm{V}$ jakém poměru se malíř nacházel $\mathrm{k}$ deskovému úřadu, bohužel prozatím není známo. Moravské úřední schematismy vycházející od první poloviny 18. století žádnou takovou profesní pozici při deskovém úřadě neevidují. Lze se domnívat, že malíri byli za účelem výzdoby (nejen) kvaternů majestátů bud’ zaměstnáváni smluvně jako externisté (jako jediný je doložen Matthias Bronnenmayer, „Zeichenmeister“ brněnské c. k. nor-

57 Srov. např. listinu olomouckého kanovníka Vincence Konopky z 23. 3. 1835 v Zemský archiv v Opavě, pob. Olomouc, Metropolitní kapitula Olomouc, inv. č. 2285.

58 Z edic a soupisů výběrově Fiala, Michal - Hrdlička, Jakub - Županič, Jan: Erbovni listiny Archivu hlavního města Prahy a nobilitačni privilegia studentské legie roku 1648. Praha 1997; Fiala, Michal - Krejčík, Tomáš: Erbovni listiny Archivu Národního muzea. Praha 2001; Müller, Karel: Erbovni listiny bohemikálního charakteru ve státním archivu ve Vratislavi. Zpravodaj Klubu genealogů a heraldiků Ostrava 30-31, 1988, s. 10-12; týž: Erbovni listiny v archivech Slezska a severni Moravy. Opava 2001 + dodatky 1-3; Brňovják, Jiří - Hrdlička, Jakub - Fiala, Michal - Krejčík, Tomáš: Litterae armorum. Erbovní listiny v Národním archivu v Praze. Multimediální edice. Ostrava - Praha 2011; Županič, Jan - Fiala, Michal - Koblasa, Pavel: Šlechtický archiv c. k. ministerstva vnitra. Erbovní listiny Národního archivu, Státního oblastního archivu v Praze, Archivu hlavního města Prahy (dodatky), Archivu Národního muzea (dodatky). Praha 2014. Ze zahraniční produkce zejm. Faust, Ovidius: Archív mesta Bratislavy 1. Súpis erbových listín zemianských. Bratislava [1933]; Pfeifer, Gustav: Wappen und Kleinod. Wappenbriefe in öffentlichen Archiven Südtirols. Bozen 2001; Seibold, Gerhard: Wappenbriefe aus Bayerisch Schwaben. In: Herold Jahrbuch. Neue Folge 14. Insingen 2009, s. 235-253; týž: Der Wappenbrief. Ein Kompendium. 1-2. Köln 2019. Z internetových zdrojů obsahujících množství reprodukcí nobilitačních listin především Monasterium.net, https://www.monasterium.net/ mom/IlluminierteUrkundenWappenbriefe/collection, citováno 29. 9. 2020.

59 Řada nových členů stavovské obce si nechala vymalovat získaný erb do Knihy pánů rytíŕo̊n, někteří z nich tak učinili dokonce současně do kvaternů majestátů. Srov. MZA, A 3, inv. č. 44 a David, J.: Kniha, s. 154-159. 
mální školy, který signoval několik maleb z let 1790-1811, kvatern L), nebo - jak ukazují další unikátní př́́klady signovaných maleb z 30.-40. let 19. století (kvatern M) - jimi byli nižší úředníci zaměstnanci stavovské registratury a expedice (pro vklady z let 1837-1839 a 1844 doložen praktikant Johann Baptista Schenkl a v letech 1839 a 1845 kancelista Franz Seraphin Skalicky). ${ }^{60}$ Jak dokládá datace 16. 11. 1835 a signatura F. S. Skalického při erbovním vyobrazení v intabulaci z roku 1780 (kvatern E), některé erby mohly být do intabulovaných nobilitačních listin vymalovány se značným zpožděním. ${ }^{61}$

Větší část erbů byla vymalována co nejjednodušším způsobem, a tedy nikoliv po vzoru originální erbovní miniatury, pro které je typické bohaté iluzivní pozadí ve čtvercovém zlatém rámu. Omezila se pouze na vyobrazení vlastního erbu umístěného do oválné, nejčastěji rostlinné kartuše, jež byla v posledních letech 17. století vystřídána čtvercovým či obdélníkovým zlatým rámem. Vlastní erb byl podkreslen iluzivním stínem dopadajícím na pozadí, jež bylo bud' prosté, nebo bylo damaskováno jemným rostlinným (akantovým) vzorem. ${ }^{62} \mathrm{~V}$ několika př́ípadech byla do textu intabulovaného majestátu vymalovaná nepravá miniatura, tj. erbovní vyobrazení, jež bylo umístěno do kartuše nebo rámu obsahujícího některé prvky iluzivní architektonické nebo krajinné výzdoby originálu erbovní miniatury nebo jejich deriváty. Povětšinou tak byla z původních miniatur odstraněna symbolika vydavatele (především státní heraldika), podle níž bylo možno rovněž určit kancelářskou provenienci listiny. $\mathrm{V}$ některých případech ale byla malířem více či méně zdařile okopírována celá původní erbovní miniatura se všemi dobovými výtvarnými i symbolickými aspekty. Již v kvaternu E (od 1717) se objevují prostá ztvárnění erbů bez jakéhokoliv rámování, která v některých případech až nápadně připomínají barevné erbovní návrhy z nobilitačních spisů české dvorské kanceláře a jejích nástupců, jež byly po schválení erbovním censorem přiloženy do konceptů k sestavení blasonu a vymalování miniatury do čistopisu listiny. ${ }^{63}$ Spíše jen ojediněle byly vymalované erby umístěny na mramorový sokl, povětšinou mimořádně dynamicky ztvárněný (šlo o derivát jednoho ze základních architektonických komponentů erbovních miniatur druhé poloviny 18. a první poloviny 19. století), či stály na půdě.

V kontextu popisu heraldické výzdoby kvaternů majestátů je třeba připomenout bohatě ilustrovanou titulní stranu kvaternu C (veden v letech 1686-1701), jedinou svého druhu v celé řadě studovaných kvaternů, vyhotovenou zjevně podle vzoru titulních stran předbělohorských deskových kvaternů: trojice erbů př́íluší nejvyššímu zemskému

60 Viz příslušné ročníky Schematismus für das Markgrafthum Mähren und Herzogthum Schlesien a ProvinzialHandbuch für Mähren und Schlesien.

61 Patrně se tak stalo na přání některého z potomků rodu Rodenů z Hýřenova (snad Karla Františka [1781-1863], majitele Hrotovic), nebot intabulovaná listina se dotýkala udělení starého stavu svobodných pánů bratrům Karlovi, Josefovi a Tadeáši Rodenům z Hýřenova z 12. 5. 1718. MZA, A 3, E 63, fol. 62v; k rodu Mašek, Petr: Šlechtické rody v Čechách, na Moravě a ve Slezsku od Bílé hory do současnosti, 2. Praha 2010, s. 164 .

62 K historickému vývoji erbovních miniatur a jejich typologii zejm. Krejčík, Tomáš: Nové poznatky o vývoji erbovnich a nobilitačnich listin. In: Litterae, s. 11-72.

63 K erbovní censuře Brňovják, J.: Šlechticem, s. 151-155 a týž: Zur Modernisierung der böhmischen Heraldik im Lichte der Kanzleipraxis bei Standeserhebungen der ersten Hälfte des 18. Jahrhunderts. Herold-Jahrbuch. Neue Folge 21, 2016, s. 10-15. 
komorníkovi Antonínu Františkovi hraběti Collaltovi (v úřadu v letech 1675-1696), nejvyššímu zemskému sudímu Fridrichu hraběti Oppersdorfovi (1679-1697) a nakonec nejvyššímu zemskému písaři Rudolfu Maxmiliánovi Ř́ikovskému z Dobrčic (1682-1692). V kartuších se jmény a titulaturou uvedených úředníků je v př́ípadě hrabat Collalta a Oppersdorfa navíc uvedena datace 1685, která jistě odkazuje na zřízení kvaternu C, jehož první zápis byl učiněn o rok později (téhož roku byl realizován poslední zápis do předchozího kvaternu B). ${ }^{64}$

\section{b) Panounické/dvorské intimace}

Až do poloviny 60. let 18. století byly panovnické intimace vyhotovovány ve formě reskriptu. Ačkoliv reskripty byly v české kancelářské produkci známy již v období vlády Ferdinanda I., do kancelářské praxe v českých zemích byly masivně uvedeny patrně až v souvislosti s porážkou stavovského povstání - jistě k tomu přispěly dobové poměry vedoucí k etablování panovnického absolutismu v politické i byrokratické sféře a s ním spojená zvýšená potřeba panovnického dvora písemně informovat nově konstituované zemské vlády o vydávaných panovnických nařízeních a rozhodnutích v konkrétních kauzách i v obecných záležitostech. Př́ijemcem reskriptu byl výhradě nižší, podřízený úřad, tedy v zásadě zemská vláda. Vydavatelem reskriptu byl panovník, proto byl vlastní text stylizován v subjektivní formě. Vzhledem k nepříliš velkému rozsahu vlastního textu, odpovídajícího v zásadě informativnímu účelu, byly reskripty psány nejčastěji na jeden složený dvojlist papíru. S diplomatickou formou reskriptu plně koresponduje také užívání malé panovnické titulatury. Čistopisy reskriptů byly podepsány vydávajícím panovníkem, českým nejvyšším kancléřem a sekretářem a následně byly na způsob misivy uzavřeny menší znakovou pečetí (sekretem) přitištěnou pod papírovým krytem. V této podobě a s potřebnou adresou př́ijemce uprostřed versa druhého (posledního) folia, jež sloužilo jako obálka, byly reskripty odesílány svým př́iemcům. ${ }^{65}$ Vzhledem k uzavřené formě i charakteru obsahu lze reskripty považovat za historické nástupce misiv neboli

64 Jmenované úředníky srov. v Boček, Antonín: Přehled knižat a markrabat i jiných nejuyšších důstojniků zemských v markrabství moravském. S. l., s. d. K tradiční heraldické výzdobě dalších kvaternů moravských zemských desk viz Štarha, Ivan a kol.: Moravské zemské desky 1348/1642. Břeclav 1999; Houdek, Vítězslav: Drobnomalby moravských desk zemských. Časopis Matice moravské 39, 1915, s. 77-97, srov. také originály knih s inv. č. 45 (Kniha panského stavu, 1670) a 46 (Kniha stavu rytíŕského, 1670). Naopak Kniha pánů rytírủ z let 16281690 (inv. č. 44) obsahuje heraldickou výzdobu blížící se již duchu kvaternů majestátů, srov. David, J.: Kniha, s. 154-159 a Hanáček, J.: Kniha. K heraldice v českých obdobách moravských kvaternů majestátů srov. Sedláček, Pavel: České zemské desky a heraldika (1642-1869). In: Heraldica viva 2. Sborník příspěvků z konference českých, moravských a slezských heraldiků, konané ve dnech 21.-22. ř́jna 1999 v Pardubicích. Ed. P. Vorel. Pardubice 2002, s. 79-94.

65 Srov. Čelakovský, Jaromír: O domácích a cizích registrech, zvláště o registrech české a jiných rakouských dvorských kanceláři. Praha 1890, s. 52-53, 56, 65; Letošník, Václav: Registra otevřených listů české kanceláre. Časopis Archivní školy 3, 1926, s. 36-63; Kristen, Zdeněk: Listy posélací a jejich registra v královské kancelári české až do Bílé Hory. Časopis archivní školy 5, 1927, zejm. s. 22-48; Stloukal, K.: Česká kancelářr, s. 76-77; Meissner, H. O.: Aktenkunde, s. 17-19, srov. 35-38; Hochedlinger, M.: Aktenkunde, s. 188-189; Šimara, František: Reskripty české dvorské kanceláre 1620-1740. Folia diplomatica 12, 1963-1965, č. 3-4, s. 56-58; Sulitková, Ludmila: Archivnictvi a spisová služba. Archivní materiál. Ústí nad Labem, s. d. s. 4-5, http://ff.ujep.cz/ archivnictvi/archivni_material.pdf, citováno 31. 5. 2018; srov. také Lukeš, Petr: Seznam úředniků, podpisují cích písemnosti českých panowniků 1740-1848, tamtéž, s. 60-63. 
listů posélacich (missiv, litterae clausae, Sendbriefe, Sendschreiben). Pojem reskript ve vlastních kvaternech majestátů i kvaternech slibů věrnosti v podstatě používán nebyl. Místo něj, plně s ohledem na vlastní funkci této intabulované písemnosti, úředníci deskového úřadu označovali danou písemnost v záhlavních regestech i vlastních intabulovaných písemnostech jako panovnickou rezoluci (allergnädigste Resolution, nejmilostivějši poručení), v tribunálních intimacích pak byla často popisována jako panovnická insinuace či intimace (allergnädigste Insinuation, česky Jeho Cýsařé Králov. ${ }^{e}$ M. ${ }^{t i}$ [...] Intimati). Nakonec se pozvolna prosadilo jednotné označení Intimations-Resolution či Insinuations-Resolution. ${ }^{6}{ }^{6}$

Nařízením Marie Terezie z 18. listopadu 1763 byly reskripty nahrazeny dvorskými dekrety. Panovnice zdůvodnila toto své rozhodnutí praktickou potřebou ulehčit si od náročné povinnosti osobně podepisovat všechny vydané reskripty, jejichž takřka každodenní produkce musela být minimálně v rámci západní části monarchie obrovská. Nové dvorské dekrety měly být opatřeny pouze vlastnoručními podpisy dvorského kancléře, místokancléře a dvorského rady. Absence panovnického podpisu ale neměla nijak snižovat právní váhu dekretů, jež se měla nadále rovnat dřívějším reskriptům. Formulář dekretů byl poněkud zredukován, vlastní text byl stylizován v objektivní formě hovořící o vydavateli panovníkovi ve třetí osobě singuláru. Pro dvorské dekrety byla typická spojená datační a koroborační formule „Signatum Wienn unter allerhöchst wiederholt Mayestät aufgedrückten Secret-Insigel, den [datum]. “Tato formule potvrzuje, že dekrety byly obdobně jako reskripty uzavírány panovnickou sekretní pečetí pod papírovým krytem. Jak napovídají záhlavní regesty intabulovaných dekretů, sami úředníci úřadu zemských desk označovali tuto intabulovanou písemnost z formálního hlediska jako dekret či z hlediska funkčního jako rezoluci: Intimations-Decretum, „mittelst eines höchsten Hof-Decreti ergangene Insinuations-Resolution “. Stejně tak činili i úředníci zemské vlády v intimaci zasílané deskovému úřadu. Dvorský dekret („k. k. höchster Hofdekret“) byl tedy v rámci dobové terminologie jasně odlišován od dekretů vydávaných množstvím úřadů nižších instancí. Po obsahové, ale především formální stránce je tedy vhodné považovat dvorské dekrety primárně za písemnost vlastního dvorského úřadu než za panovnickou. ${ }^{67}$

66 Pojem reskript nebyl v dobové úřední praxi neznámý, jak dokládá ojedinělé použití termínu Intimations-Rescript. Hochedlinger i Rameš definují intimát a insinuát na základě pozice vydávajícího úřadu v instanční struktuře: insinuát chápou jako zprávu bez nařizovací formy zasílanou úřadem úřadu bez zohlednění instanční nadřazenosti, zatímco intimát jako sdělení nadřízeného úřadu podřízenému (informuje o svém rozhodnutí či rozhodnutí úřadu jiného). Hochedlinger, M.: Aktenkunde, s. 215-216; Rameš, V.: Slovnik, s. 99-100. K dobové funkční variabilitě pojmů intimace/intimát a insinuace/insinuát srov. Meissner, H. O.: Aktenkunde, s. 143-145.

67 Také počátky dekretů můžeme stejně jako reskriptů sledovat v období Ferdinanda I. Čelakovský, J.: $O$ domácích a cizich registrech, s. 52; Ottũv slovnik naučný, VII. Praha 1893, s. 186; Stloukal, K.: Česká kancelár, s. 78-80; Meissner, H. O.: Aktenkunde, s. 20-22, 38; týž: Urkunden- und Aktenlehre, s. 31-33, 37-38; Culková, Dagmar: Dekrety české kanceláré v době předbělohorské. Paginae historiae 16, 2008, s. 12-14; Hochedlinger, M.: Aktenkunde, s. 192-195; Sviták, Zbyněk: Z počátků moderní byrokracie. Nejvyšší zeměpanský úřad na Moravě v letech 1748-1782. Brno 2011, s. 145-146; Rameš, V.: Slovnik, s. 52-53; Sulitková, L.: Archiunictuí, s. 4-5. 


\section{c) Intimace zemské vlády}

Tento druh písemnosti, expedované moravským královským tribunálem již od jeho vzniku a poté královskou reprezentací a komorou jako jeho nástupcem, byl z diplomatického hlediska detailně popsán již v pracích V. Vašků a Z. Svitáka. Podle znění latinsky psané datační formule, jež začínala slovy „Decretum in Tribunali Regio Brunae die [datace] “, a která byla zakončena plně rozepsanou latinskou datací, byla tato intimace výše zmíněnými historiky pojmenována dekretální misivou. V souvislosti s ustavením královské reprezentace a komory byla po roce 1749 datační formule adekvátně pozměněna na „Decretum in Consilio Caes. ${ }^{\circ}$ Regia Representationis et Camera Brunae die [datace]“, přičemž v dataci pozvolna převážilo uvádění roku arabskými číslicemi. Zemská vláda tuto písemnost používala pro písemnou komunikaci s úřady, které jí byly podřízeny a mezi něž v zásadě patřil také úřad zemských desk. Moderní diplomatické pojmenování této písemnosti jako dekretální je plně na místě, nebot jejím prostřednictvím zemská vláda de facto nařizovala deskovému úřadu vzít v potaz, popř. intabulovat zasílanou panovnickou intimaci (která sama př́slušnou publikaci požadovala): „Alß wirdt solches denen Herren zur Nachricht, undt damit sie, dem Kay. allergnädigsten Befehl gemees sich zu vorhalten wüssen mögen, hiemit bedeutet. "Dobový terminologický ekvivalent pro dekretální misivu nemáme k dispozici, nebot příslušné dílčí záhlavní regesty dotýkající se intimací zemských vlád hovoří v zásadě o obsahu písemnosti, nikoliv o ní samotné.

Vzhled čistopisů dekretálních misiv neprošel až do josefinských dob zásadními změnami. Tradičně byly adresovány kumulativně nejvyššímu zemskému písaři a všem menším zemským úředníkům, kteř́i jako šlechtici byli po této adrese oslovováni patřičným titulem „Edle und Gestrenge!“. Dekretální misivy, v intabulacích rovněž označované jako guberniální dekrety, byly zakončeny firmou, pod níž se za celý úřad podepisovali prezident (zemský hejtman), příslušný rada a sekretář. ${ }^{68}$ Až na počátku 80 . let 18. století byla mírně pozměněna datační formule, a to ve znění „Ex Consilio Caesareo-Regii Gubernii Brunae [datace]. “, po předání intabulační agendy moravskoslezskému zemskému právu ve znění „Decretum ex Consilio Judicii Provincialis Moraviae et Silesiae Bruane die [datum]“.

Dekretální misivy byly cca od roku 1786 nahrazeny značně jednoduššími guberniálními notami. Tento druh písemnosti měl původně podle instrukce z roku 1764 používat guberniální prezident ke korespondenci s vrchním vojenským velitelstvím. Mělo se jednat o dosti strohé písemnosti bez jakýchkoliv nadbytečných úvodních formalit, které měl podepisovat pouze sám prezident. Mezi adresou, která svým zněním prozrazuje adresáta i př́ijemce („Von dem mähr. schles. Landes Gubernium an die mähr. schlesisch. k. Landrechte“), a vlastním textem se nacházelo zvýrazněně slovo Nota, jež dalo vzniknout samotnému názvu písemnosti. Forma písemnosti rovněž odpovídala komunikaci vydavatele i adresáta, kteří se instančně nacházeli na shodné úrovni. Vlastní text noty byl stylizován objektivně a zakončen byl prostou datací s pouhým uvedením místa a data vydání, pod níž se podepisoval guberniální prezident. Nota nebyla opatřována pečetí. ${ }^{69}$ Jistě pro svou formální jednoduchost a nenáročnost na expedici se noty staly oblíbenou písemností zemské

68 Vašků, Vladimír: Studie o správních dějinách a pisemnostech moravského tribunálu z let 1636-1749. Brno 1969, s. 49-61 a zejm. 63-79; Sviták, Z.: Z počátki̊, s. 447-450.

69 Sviták, Z.: Z počátků, s. 444-446; Hocheldinger, M.: Aktenkunde, s. 216-218. 
vlády. Stejně jako u řady dalších písemností byly v první polovině 19. století také pro noty používány unifikované formuláře s předtištěnou hlavičkou (např. „Vom k. k. mähr. Schles. Landesgubernium ") a poměrně zdobně vyvedeným titulem Nota.$^{70}$ Úředníci registratury moravského stavovského zemského výboru, kteří zajištovali vklady do kvaternů majestátů, noty ještě v počátcích jejich užívání - jistě v souladu se zažitou praxí - označovali v záhlavních regestech za guberniální dekrety („k. k. Gubernial Intimations Dekret“), posléze vedle pojmu „hohe $k$. $k$. Gubernial Note“ rovněž užívali označení „k. k. Gubernial Intimation “. Úspěšné zavedení not do kancelářské praxe civilní administrativy chronologicky koresponduje s počátky procesu zjednodušování intabulací do kvaternů majestátů, kdy již přestaly být opisovány dvorské intimace.

\section{d) Reversy $k$ zemi}

Přestože se jednalo o listiny vydávané soukromými osobami, tyto písemnosti si po celou dobu své existence uchovávaly víceméně pevně danou obsahovou i formální strukturu, jež do jisté míry navazovala na podobu reverzů k zemi doby předbělohorské. ${ }^{71}$ Skutečnost, že reversy byly listinami soukromými, se podepsala především na jistém, avšak mírném variování vlastního textu, zřejmě nikdy ale nedošlo k zásadnějším odchylkám. Autoři reversů (snad to byli úředníci či písaři zeměpanských, vrchnostenských či městských úřadů, popř. zemští advokáti), kteří je připravovali pro jejich vydavatele, byli s jejich tradiční formou nepochybně plně seznámeni - jistě využívali starších vzorů, které se nacházely ve stavovské registratuře při úřadu zemských desk. I v nevelkém rozsahu textu reversů lze rozlišit několik stabilních tradičních formulářových pasáží. Intitulace reversů plynule přecházela v promulgaci, např.: „Ich [...] urkunde hiemit in Crafft dieses Brieffs“, „Já [...] vyznávám tímto reversem vỉbec předevšemi [...]“. Intitulace často obsahovala kromě jména vydavatele a plné titulatury s výčtem držených statků také uvedení profese či zastávaných úřado̊. Promulgace většinou rovněž plynule přecházela v naraci, v níž vydavatel dokazoval, že je k složení reversu podle znění OZZ oprávněn, tj. je šlechtického stavu, vlastní inkolát v českých zemích a vykonal přísahu panovníkovi. Uváděné skutečnosti byly často doplněny o data zisku těchto panovnických milostí. Přibližně do poloviny 40. let 17. století připomínala dispoziční část textu znění ústní přísahy dědičné poddanosti, jak ji předepisovalo moravské OZZ. Panovník zde však byl na rozdíl od textu přísahy zmiňován neosobně. Namísto ústního závazku, že dotyčný se bude chovat jako řádný a loajální poddaný, jenž je ochoten panovníka informovat o všech existujících či chystaných nepravostech, a který za dodržení svého slibu prosí Pána Boha i Pannu Marii, se v textech reversů nachází slib dodržovat všechna dosavadní i budoucí moravská zemská

70 Viz MZA, A 8, sg. E 2, kart. 382-395. Prostřednictvím sporadických zmínek se dozvídáme rovněž o užívání not dvorskou kanceláří v komunikaci s rovnocennými dvorskými úřady (zejm. nejvyšším soudním místem): kancelář takto informovala své dvorské „partnery“ o uskutečněné nobilitaci či udělení inkolátu. Směrné koncepty se dochovaly v dobových nobilitačních a inkolátních spisech. K pojmu „směrný koncept“ srov. Stloukal, K.: Česká kancelář dvorská, s. 54.

71 Kameníček, František: Zemské sjezdy a sněmy moravské. Jejich složení, obor působnosti a význam od nastoupení na trůn krále Ferdinanda I. až po vydání OZZ (1526-1628), 3. Brno 1905, s. 34, 40-48; Kalousek, J.: České státni právo, s. 152-153. Pro české poměry srov. mimořádně detailní rozbor v Starý, M.: Sousedé, s. $136-159$. 
zřízení a práva a chovat se jako řádný obyvatel této země. Od poloviny 40. let 17. století přibližně až do let 1783/1784 byla výše popsaná dispoziční část reversů rozdělena do dvou oddělených pasáží, mezi něž byl umístěn výslovný slib dodržovat moravská zemská zřízení a zemská práva. Tato skutečnost ještě více podtrhovala striktně zemský charakter reversů k zemi. Nová znění jurament fidelitatis z let 1723 a 1726 do textů reversů v podstatě nezasáhla. ${ }^{72} \mathrm{~V}$ období od poloviny 80 . let 18 . století byly dispoziční části textu již viditelně zredukovány, aniž by tím byl narušen obsahový smysl jejich sdělení. Pro závěrečnou fázi vývoje reversů k zemi, kterou ukončilo jejich odstranění v polovině 19 . století, je navíc typické výslovné uvedení, že revers byl vydán nejen za osobu vydavatele, ale rovněž i všechny jeho řádné manželské potomky, a - od počátku 19. století - také připojování podpisů a přitištění pečetí dvou svědků a notáře, které dosvědčovaly řádné vyhotovení originálu reversu.

Reversy k zemi byly tradičně vyhotovovány formou prosté pergamenové listiny, podepsané a zpečetěné jejich vydavateli. Přijetí úředníky zemské vlády bylo potvrzeno datovanou prezentační poznámkou, připsanou na její rub. Po provedené intabulaci byl tamtéž připsán stručný regest a číslo, které jistě odkazovalo na umístění v konkrétní sbírce reversů ve stavovské registratuře. Jméno a popř. profesní post vydavatele (zejm. u duchovních) bývaly rovněž připisovány na přední stranu pliky či na pergamenový proužek, jenž sloužil k připevnění vydavatelovy pečeti. Na rubovou stranu listiny byly rovněž připisovány obsáhlé datované registraturní poznámky, které detailně informují o intabulaci reversu a doprovodné intimace zemské vlády (označované jako tribunální dekret) a o vyhotovení potvrzení (Attestatum), jenž bylo deskovým úřadem zřejmě zasíláno zemské vládě (v příslušném aktovém materiálu se však nedochovalo). Registrační poznámka byla zakončena latinskou datační formulí ve znění Actum apud Regias Tabulas Marchionatus Moraviae, Brunae Anno et Die ut supra (vlastní datum se nacházelo hned na začátku poznámky). Datace poznámky se přirozeně shoduje s datací v záhlaví příslušného vkladu. Poznámku podepisoval registrátor deskového úřadu. ${ }^{73}$

Na konci 18. století reversy k zemi ztratily svou dřívější podobu pergamenové charty a svým vyhotovením na papírový dvojlist připomínaly jakýkoliv jiný běžný úřední dokument či dopis. Rovněž na konec jejich textu, pod podpisem a přitištěnou pečetí vydavatele, byla připojena registraturní poznámka v tradičním znění, zpravující o číslovaném nařízení moravského stavovského zemského výboru k intabulaci. Registraturní poznámka ve znění „Actum in Registratura Inclytorum Dominorum Statuum Marchionatus Moraviae Brunae die et Anno ut supra. “ současně dokládá, že vedení kvaternů majestátů a realizaci jednotlivých intabulací měl od poloviny 90. let 18. století na starostí moravský stavovský zemský výbor, konkrétně jeho registrátor a expeditor. Tato velmi prostá forma reversů vyhovovala nejen duchu doby, ale i následné potřebě připojovat vedle podpisu a pečeti vydavatele také obdobné ověřovací prostředky dvou svědků a notáře. Co se týče kvality vyhotovení textu, papírové reversy k zemi vykazují značné rozdíly - některé byly napsány

72 Znění slibu v moravském OZZ viz Obnovené zř́zeni, s. 4-7, ke zněním z let 1723 a 1726 viz Jaksch, P. K.: Gesetzlexikon, VI, s. 172-174. Ke znění reversů srov. Hasner, Joseph: Handbuch des landtäflichen Verfahrens im Königreiche Böhmen. Prag 1824, s. 222-224. 
vysloveně kaligrafickým písmem a pomocí velkosti písma, odstavců a mezer důsledně oddělovaly jednotlivé pasáže textu, některé na jakékoliv formy zdobnosti v podstatě rezignovaly. ${ }^{74}$

Revoluční léta 1848-1849, během nichž byly dosavadní stavovské ústavy nahrazeny konstituční monarchií, přinesla rovněž definitivní odstranění stavovských privilegií a s nimi také systému stavovského přijímání do zemských stavovských obcí reprezentujících politicky privilegovanou část společnosti. Inkolát jako zásadní podmínka držby deskových statků v historických českých zemích byl zrušen ministerským nařízením z roku 1849 a císařskými patenty z let 1852 a 1853. S odstraněním stavovství přirozeně ztratily své opodstatnění i reversy k zemi. ${ }^{75}$ Uváděné společenské, politické i legislativní změny nutně zapř́ičinily také ukončení dvousetleté historie vedení moravských kvaternů majestátů. Poslední habilitační písemnosti, které byly do kvaternu M intabulovány roku 1852, byly vydány v letech 1848 a $1849 .{ }^{76} \mathrm{~K}$ intabulaci obou vkladů došlo na základě rozhodnutí moravského stavovského zemského výboru, který byl (znovu)zřízen na konci května 1848 a se značně omezenými pravomocemi provizorně působil až do roku 1861, kdy byl na základě ustavení nového moravského zemského sněmu (umožněného tzv. únorovou ústavou) nahrazen novým zemským výborem. Uzavřený poslední kvatern majestátů zemských desk byl založen do zemského archivu spravovanému zemským výborem, v němž se již z roku 1789 nacházely všechny předchozí kvaterny majestátů i slibů věrnosti s příslušnými repertáři. Spolu s kvaterny majestátů byla rovněž uzavřena většina stávajících deskových knih, které po obsahové stránce již nevyhovovaly právním poměrům občanské společnosti. Dále byly vedeny již jen hlavní řady knih evidujících velkostatkový majetek, k jejich zániku nakonec došlo v polovině 80 . let 19 . století. $^{77}$

74 Srov. sporadicky dochované originály reversů k zemi v MZA, A 8 Zemská registratura, sg. E, kart. 382-395.

75 Brňovják, J.: Šlechticem, s. 120-128; Starý, M.: Inkolát, s. 811; Adamová, Karolina: K českému inkolátu. Právněhistorické studie 41, 2012, s. 193.

76 MZA, A 3, inv. č. M, fol. 156r-156v. Jejich obsah již předznamenával nové poměry: šlo o certifikáty opavského krajského úřadu o nabytí rakouského státního občanství Henrichem hrabětem Arcem, majitelem panství Hoštálkovy na Opavsku.

77 Poslední kvaterny evidující velkostatkový majetek (bývalý dominikál) byly moravským zemským soudem předány do archivu roku 1884. Kocman, A. a kol.: Prưvodce, s. 170-173. V Čechách byla patrně habilitační agenda ukončena již roku 1824, kdy byl uzavřeny trhové kvaterny přiznání se k zemi a ke stavům. Kvaterny evidující nobilitační privilegia, definitivně přestaly být používány v letech 1861, resp. 1869. České zemské desky zanikly jako takové v 80 . letech, kdy byla ukončena řada hlavních pozemkových knih. Srov. Burdová, P.: Desky zemské, s. 425-432 a Kůrka, P: Desky, s. 133. 

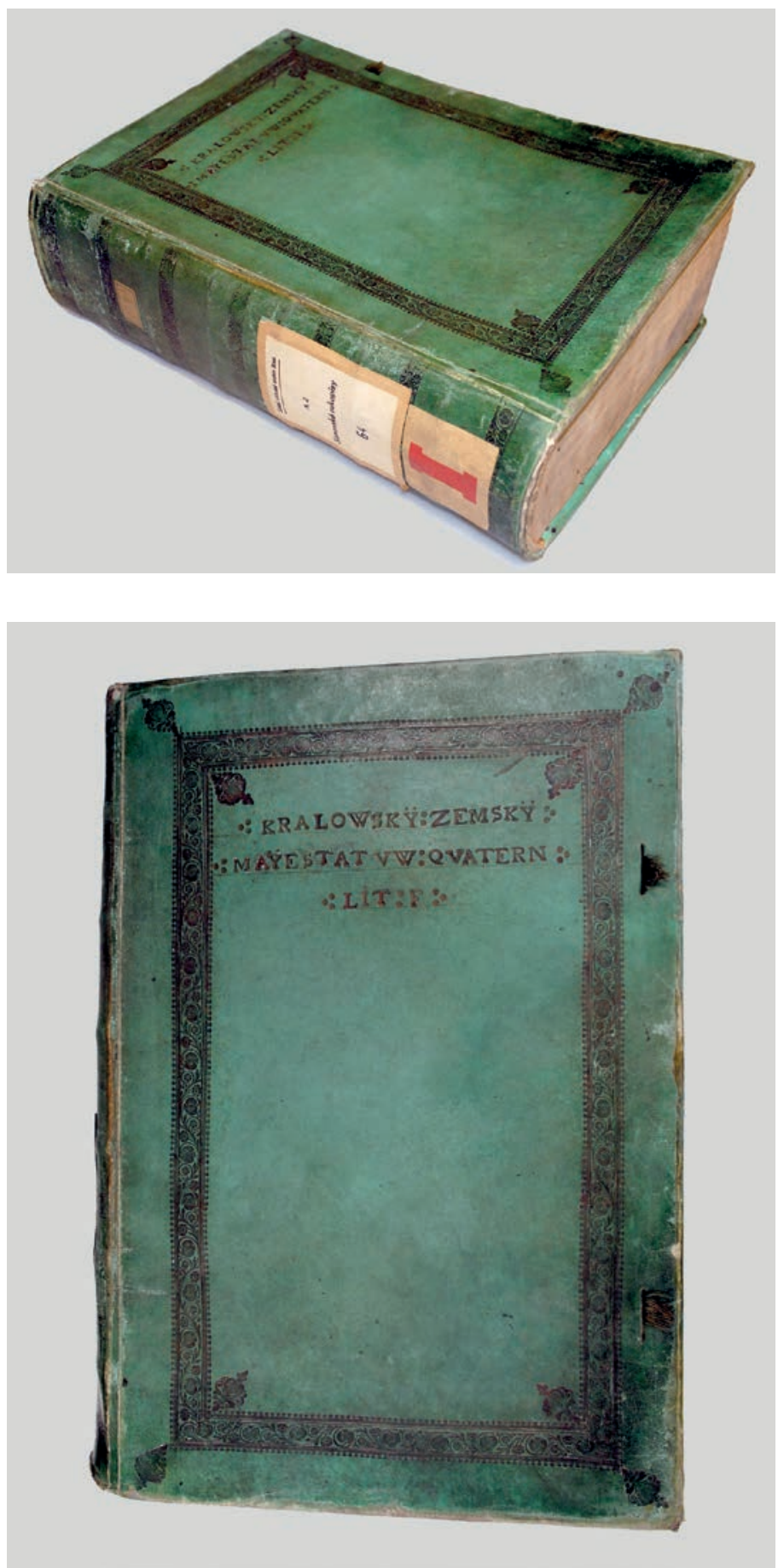

Obr. 1a, b: Zrestaurovaná vazba kvaternu majestátů lit. F z let 1732-1743 (MZA, A 3 Stavovské rukopisy, inv. č. 64) 


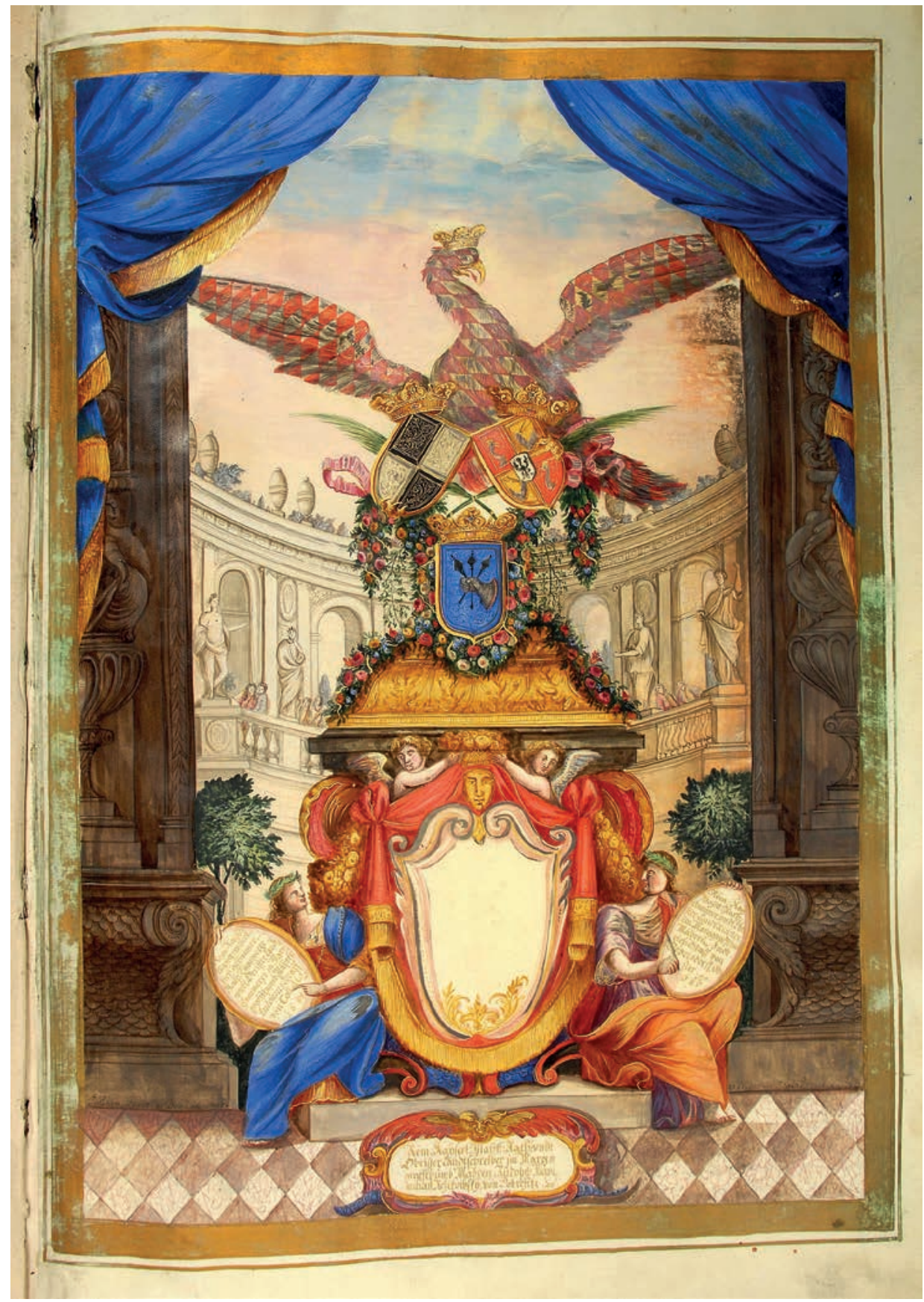

Obr. 2: Titulní strana kvaternu lit. C z let 1686-1701. Malba obsahuje erby nejvyššího zemského komorníka Antonína Františka hraběte Collalta, nejvyššího zemského sudího Fridricha hraběte Oppersdorfa a nejvyššího zemského písaře Rudolfa Maxmiliána Říkovského z Dobrčic (MZA, A 3 Stavovské rukopisy, inv. č. 61, fol. 5r) 

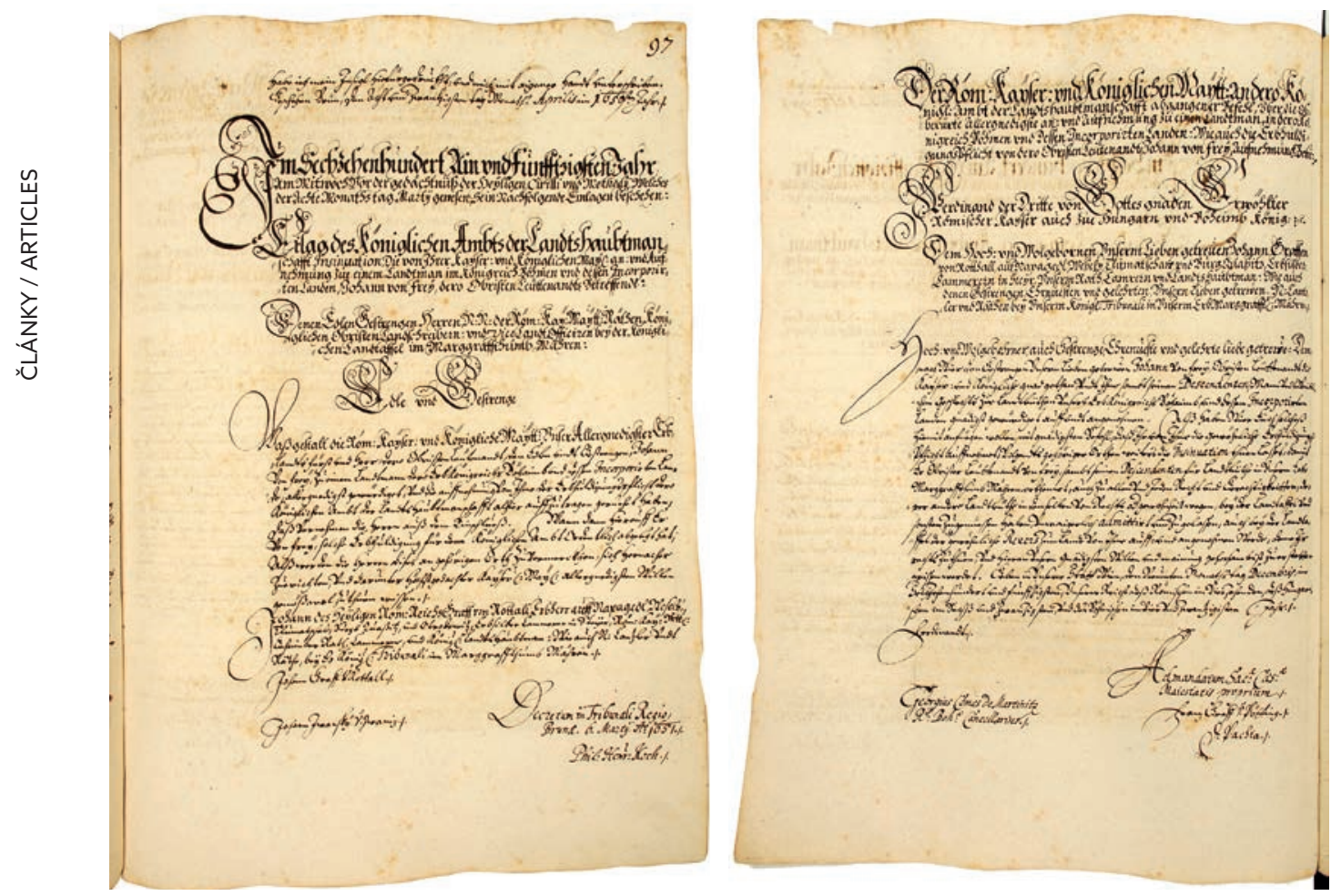

Obr. 3 a, b: Př́klad intabulace v kvaternu A (veden v letech 1642-1669). Vklad z 8. 3. 1651: intimace moravského královského tribunálu adresovaná úřadu zemských desk ohledně panovnického povolení Johannu von Frey k vykonání slibu věrnosti u tribunálu, Brno 6. 3. 1651; reskript intimující panovníkovo povolení, aby J. Frey vykonal slib věrnosti u tribunálu, Vídeň 9. 12. 1650

(MZA, A 3 Stavovské rukopisy, inv. č. 59, fol. 97r-v) 

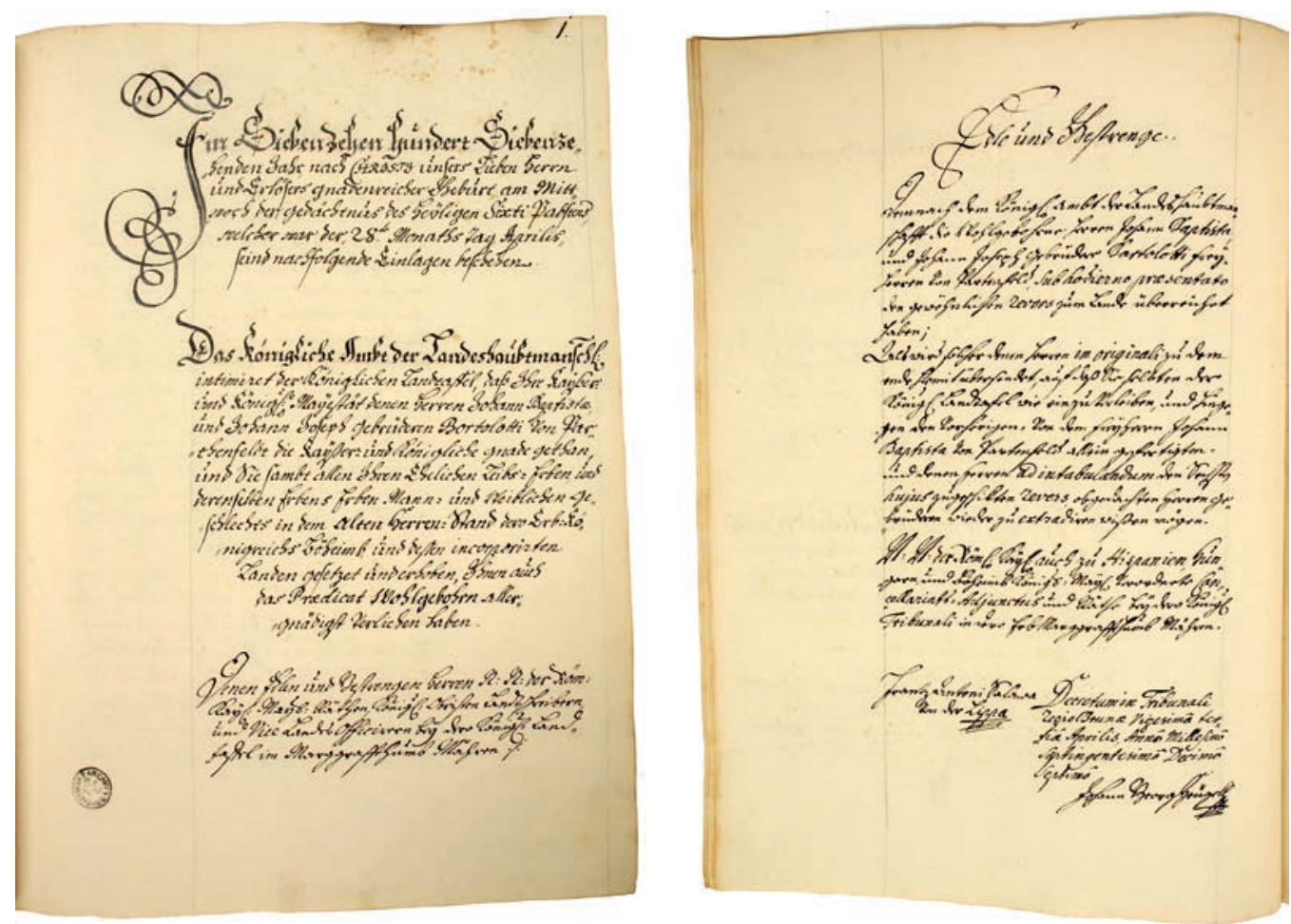

Obr. 4 a, b: Př́klad intabulace v kvaternu E (veden v letech 1717-1731). Vklad z 28. 4. 1717: intimace moravského královského tribunálu adresovaná úřadu zemských desk informující o povýšení Johanna Baptisty a Johanna Josepha Bartolottiů von Partenfeld do starého panského stavu, Brno 7. 11. 1704 (MZA, A 3 Stavovské rukopisy, inv. č. 63, fol. 1r-v) 


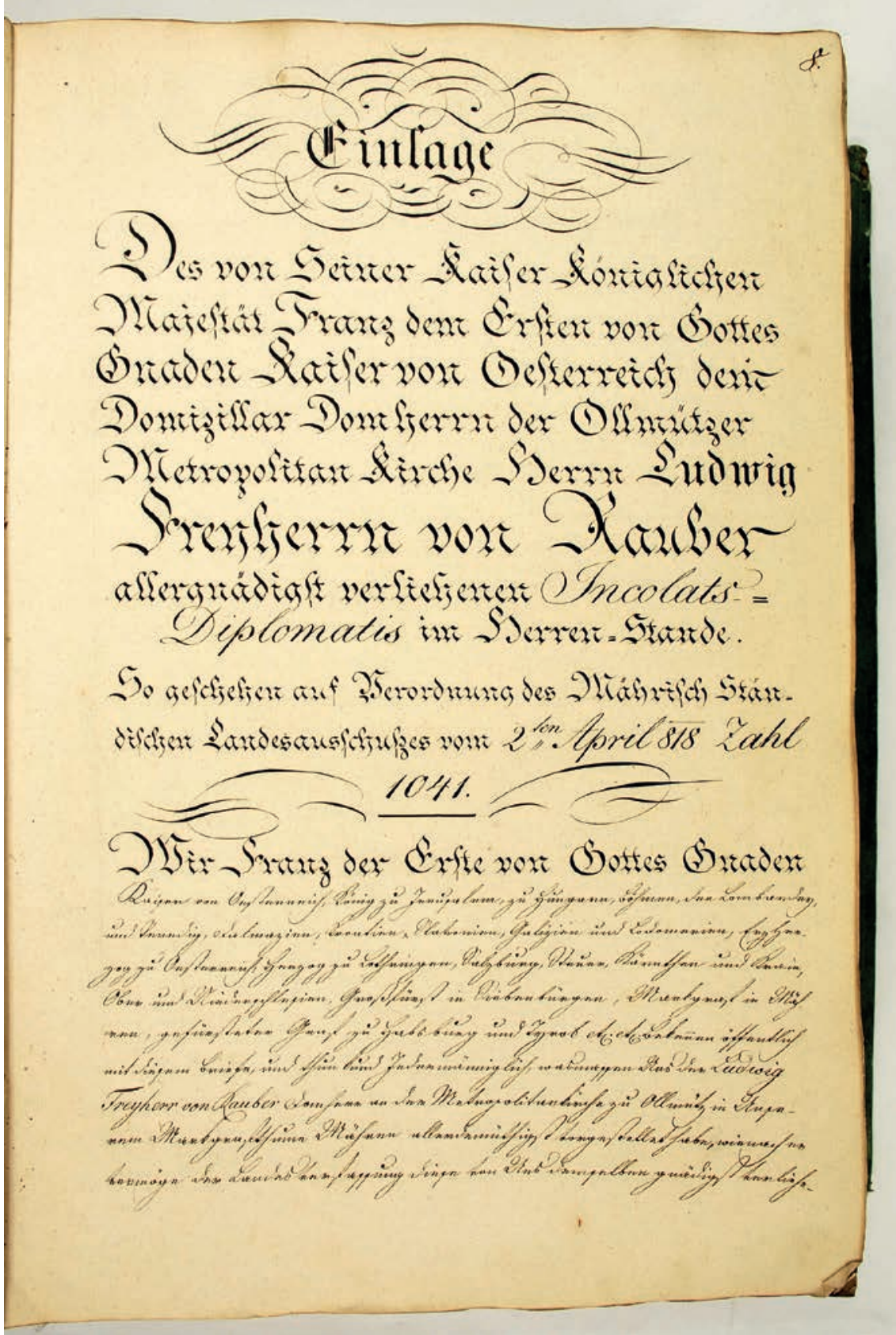

Obr. 5: Př́klad intabulace do kvaternu M (veden v letech 1816-1852). Titulní strana vkladu učiněného na základě nařízení moravského zemského výboru z 2. 4.1818 a obsahujícího opis listiny, v níz František I. udělil Ludwigovi svobodnému pánu Rauberovi inkolát v panském stavu, Vídeň 10. 6. 1817

(MZA, A 3 Stavovské rukopisy, inv. č. 70, fol. 8r) 


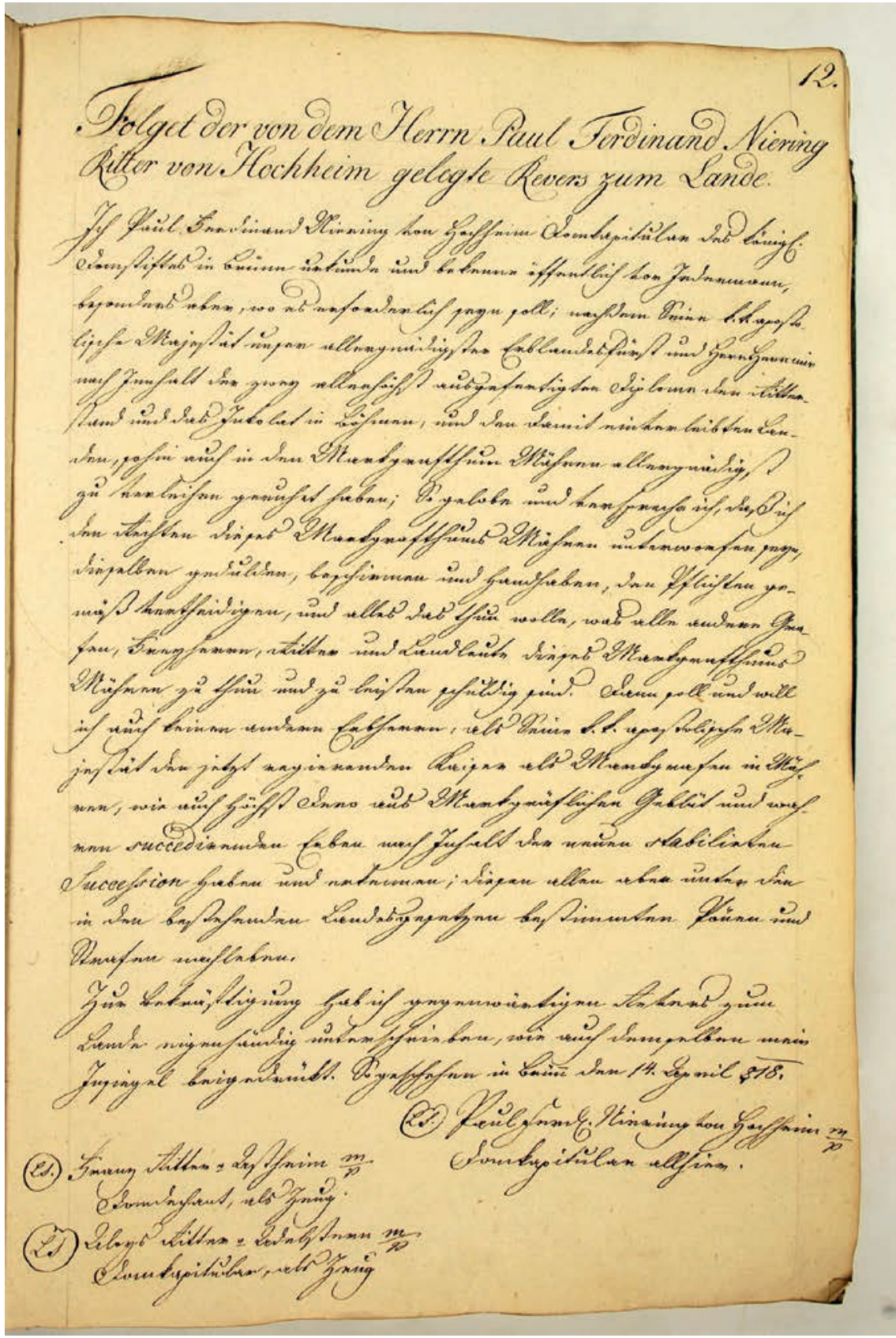

Obr. 6: Př́klad intabulace do kvaternu M (veden v letech 1816-1852). Opis reversu k zemi Paula Ferdinanda rytîre Nieringa von Hochheim, Brno 14. 4. 1818, vklad učiněn na základě nařizení moravského zemského výboru z 10. 5. 1818

(MZA, A 3 Stavovské rukopisy, inv. č. 70, fol. 12r) 


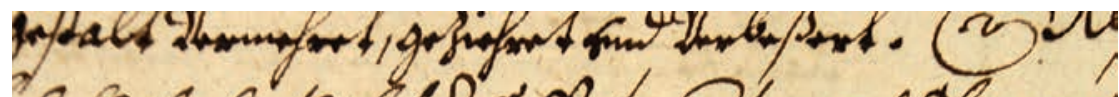

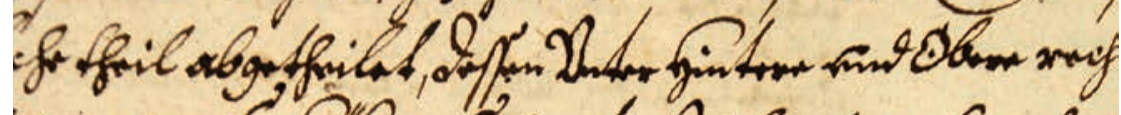

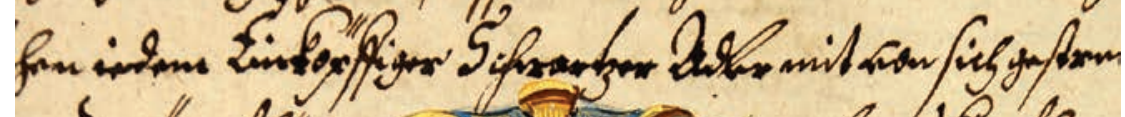

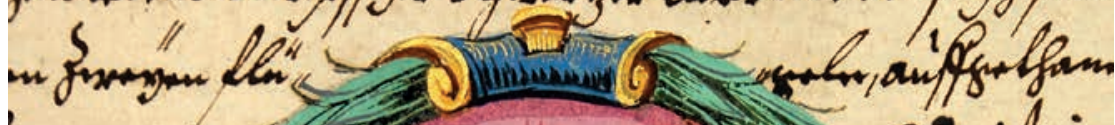
ingern, 11 anomidmo

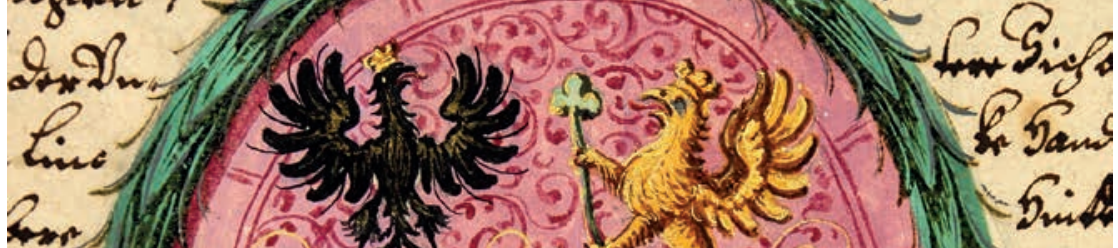

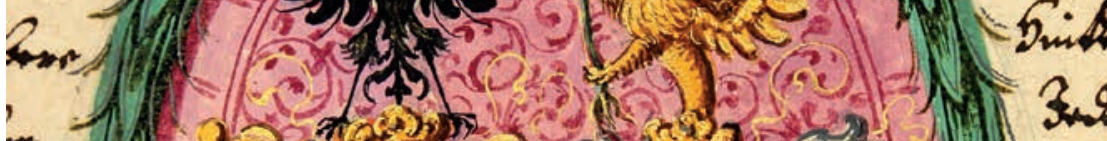

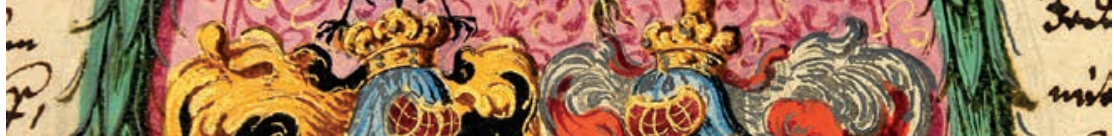
mit

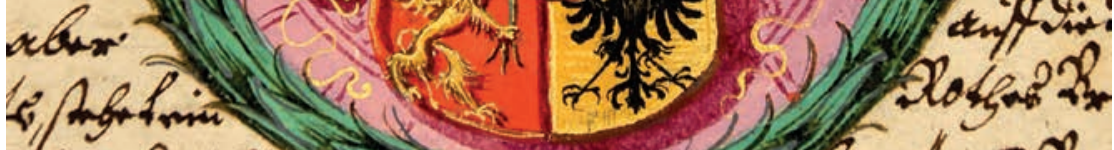

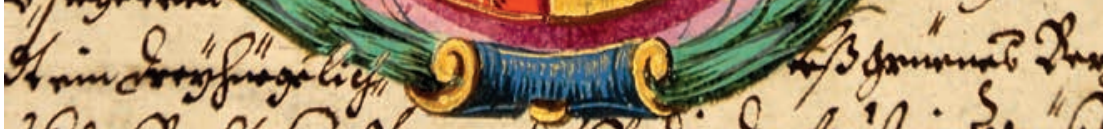

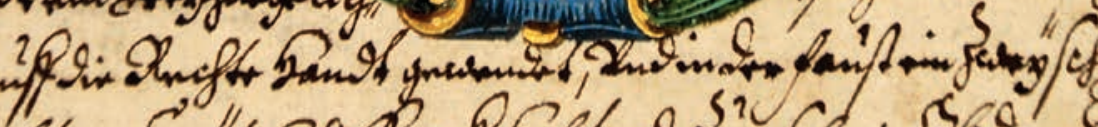

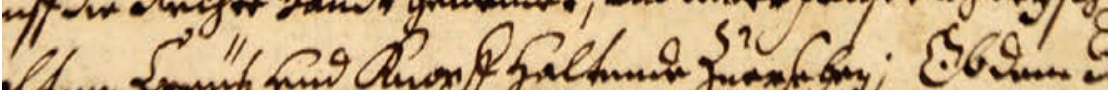

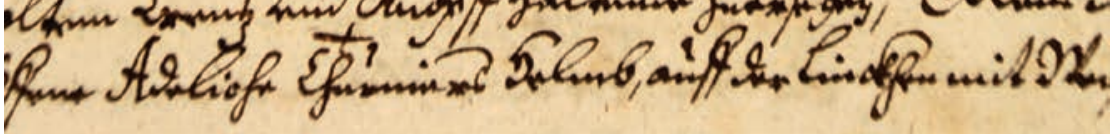

Obr. 7: Erb Bartholomea Sylvestra Gierolly v listině z 15. 5. 1649 (Prešpurk), v níž mu Ferdinand III. potvrdil starožitný šlechtický pưvod a udělil erb a přídomek von Greifenberg.

Př́klad jednoduchého erbovního vyobrazení (erb umístěn do oválné, nejčastěji rostlinné kartuše s prostým nebo damaskovaným pozadím), jež ve vkladech nobilitačních listin převažovalo do konce 18. století. Vklad do kvaternu A z 26. 4.1649 (MZA, A 3 Stavovské rukopisy, inv. č. 59, fol. 121r) 


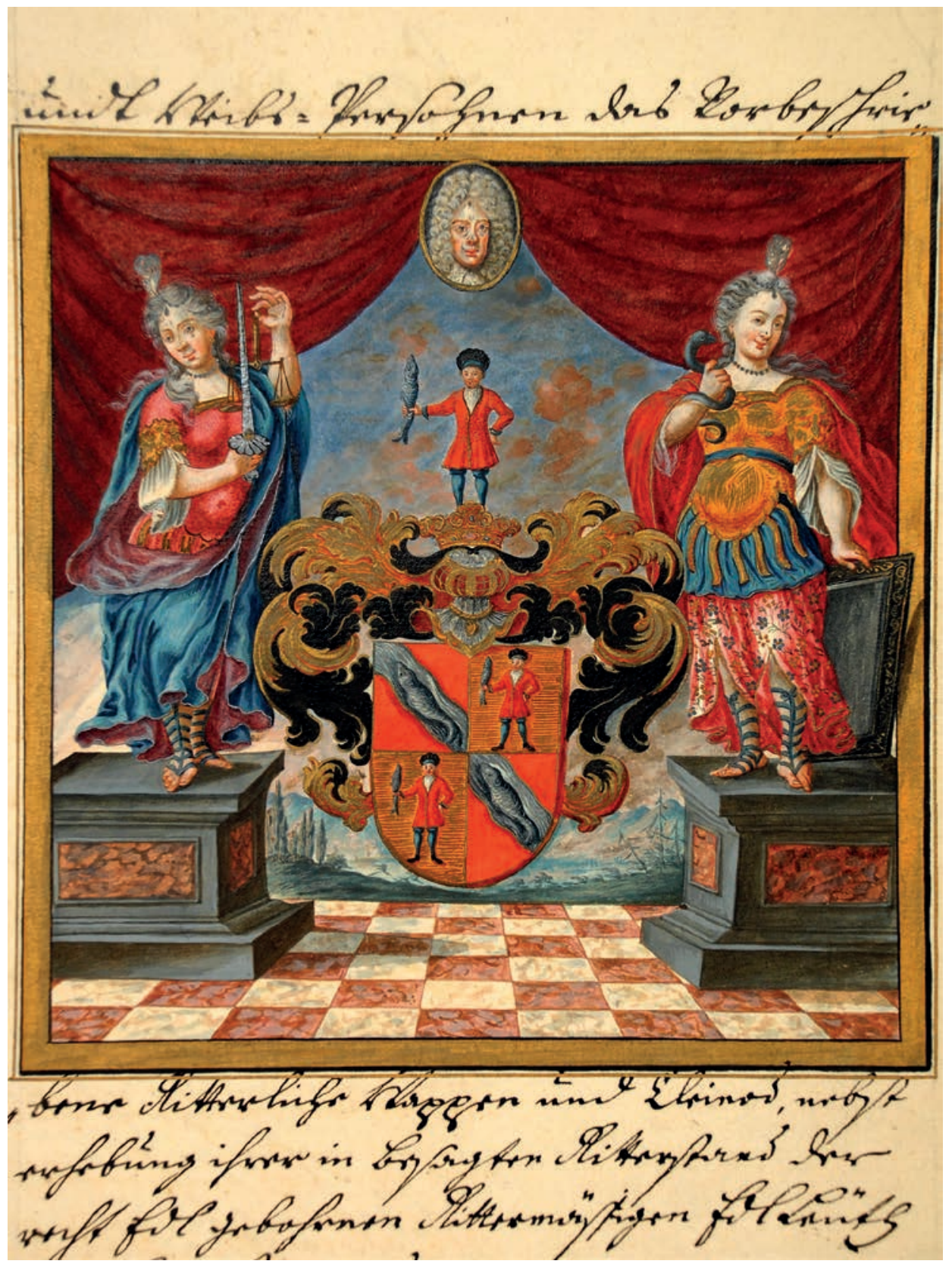

Obr. 8: Kopie původní erbovní miniatury v listině Josefa I. povyšující Georga Thomase Sabathina (Sabatuina) do českého rytî́rského stavu, Vídeň 6. 10. 1705.

Vklad do kvaternu D z 22. 4. 1717

(MZA, A 3 Stavovské rukopisy, inv. č. 62, fol. 440r) 


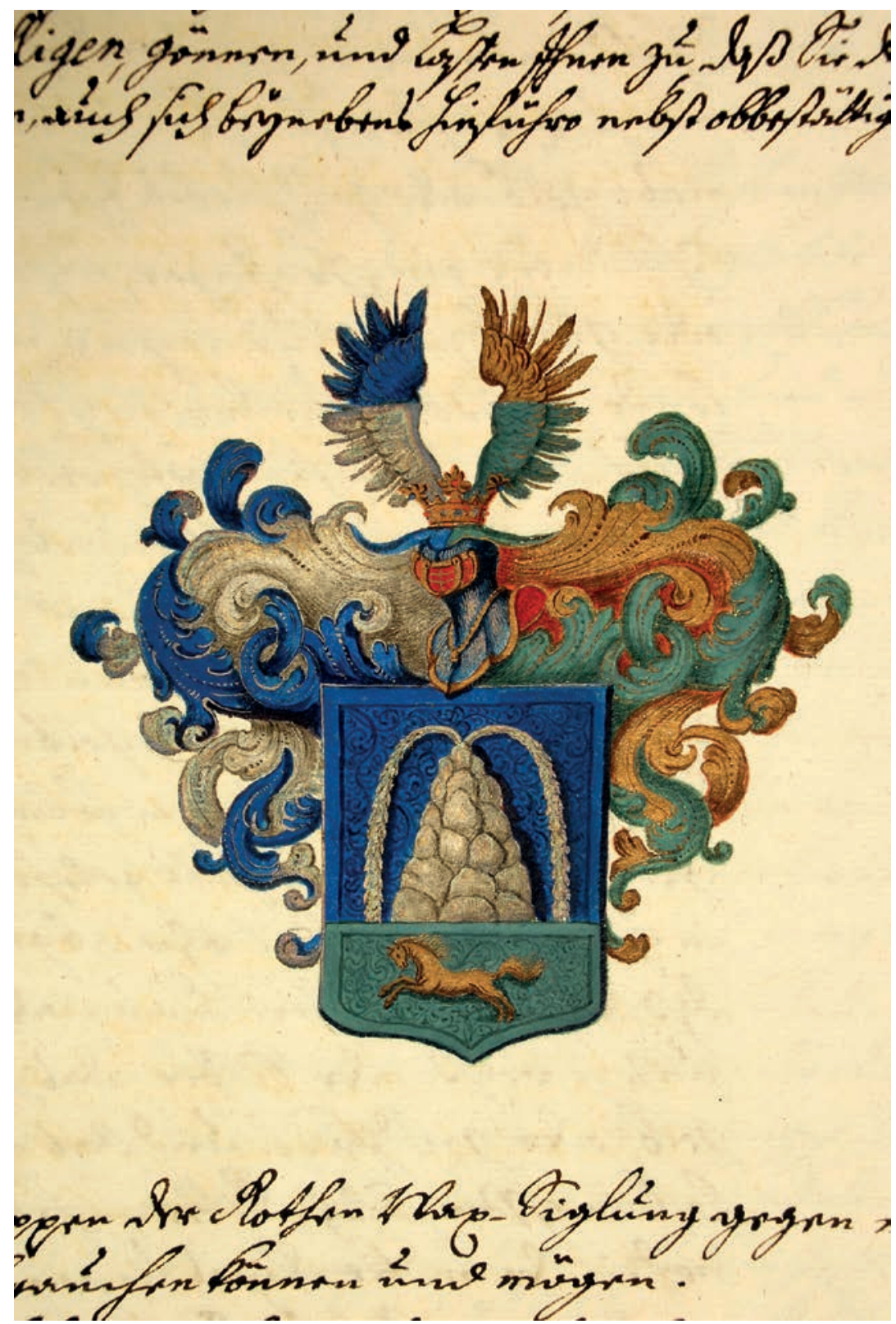

Obr. 9: Erb Johanna Josepha Nosse von Nossberg v listině z 18. 11. 1727 (Vídeň), v níž byl Karlem VI. povýšen do českého rytířského stavu. Př́klad vyobrazení erbu prostého jakéhokoliv rámování, které bylo často užíváno od počátku 18. století až do zániku kvaternů majestátů v polovině 19. století. Vklad do kvaternu E z 14. 6. 1728 (MZA, A 3 Stavovské rukopisy, inv. č. 63, fol. 354v) 


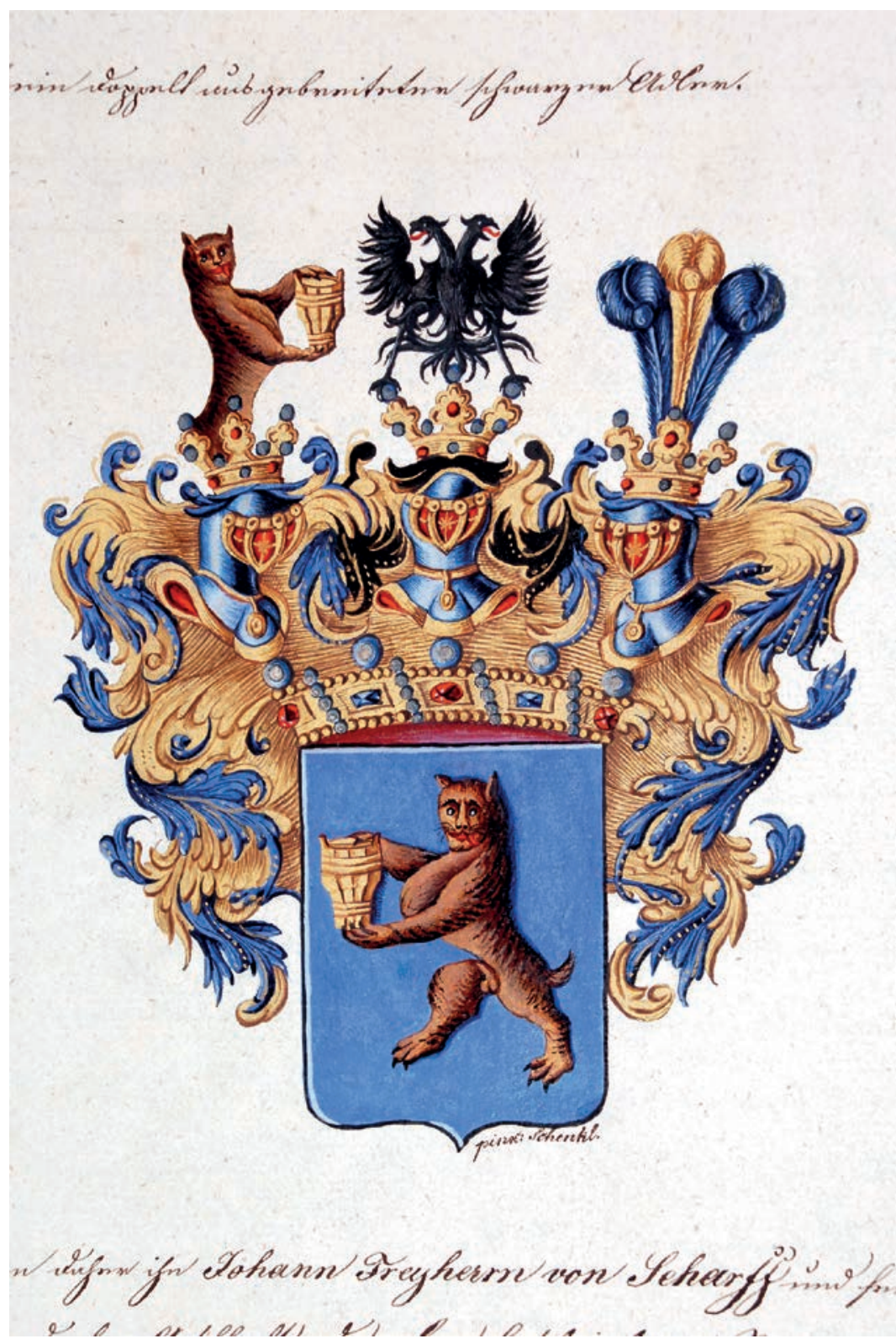

Obr. 10: Erb Johanna von Scharff v listině z 25. 2. 1813 (Vídeň), v níž byl Františkem I. povýšen do stavu svobodných pánů rakouského císařství. Vklad do kvaternu M na základě nařízení moravského stavovského výboru ze 4. 5. 1838. Malba je signována „pinx. Schenkl", autorem byl zřejmě praktikant stavovské registratury a expedice Johann Baptista Schenkl (MZA, A 3 Stavovské rukopisy, inv. č. 70, fol. 116v) 


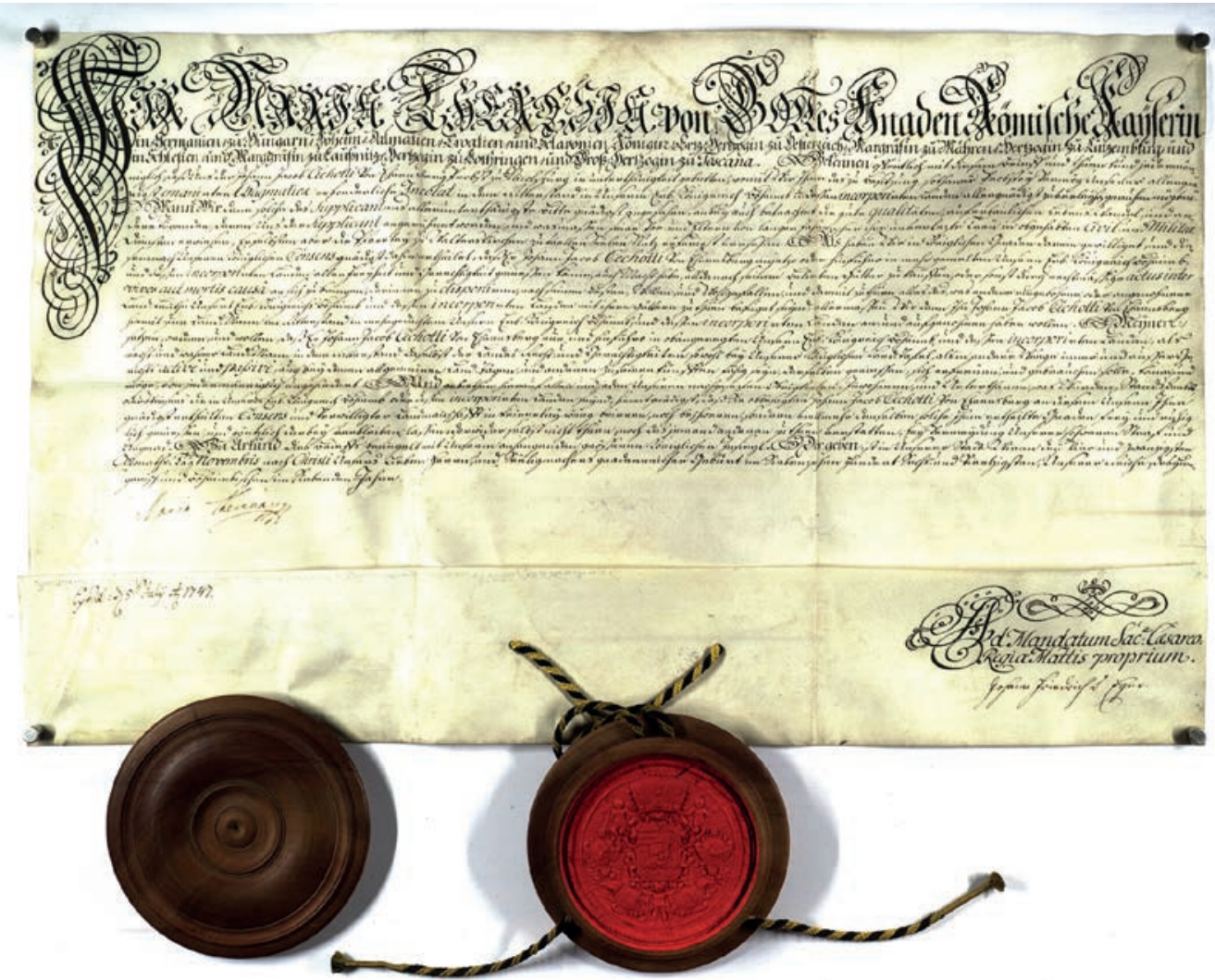

Obr. 11: Inkolátní listina pro Johanna Jacoba Cechottiho von Ehrensberg, probošta kolegiátní kapituly sv. Václava v Mikulově, Vídeň 24. 11. 1746

(Diecézní archiv Biskupství brněnského, Kapitula Mikulov, sg. 1746 XI 24) 


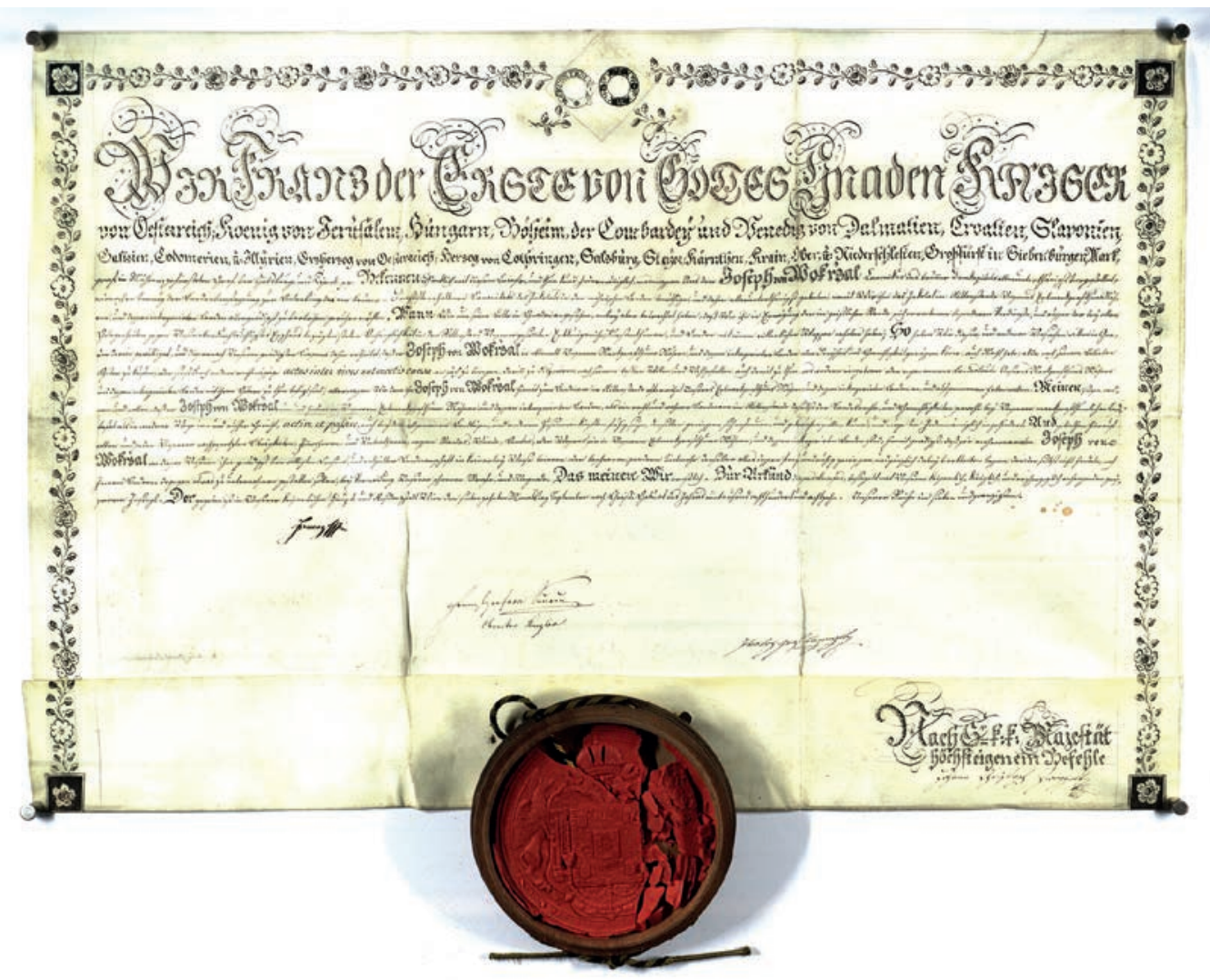

Obr. 12: Inkolátní listina pro Josefa von Wokřál, kanovníka kolegiátní kapituly sv. Petra a Pavla na Petrově v Brně, Vídeň 17. 9. 1818

(Diecézní archiv Biskupství brněnského, Kapitula sv. Petra a Pavla v Brně, sg. 1818 IX 17) 


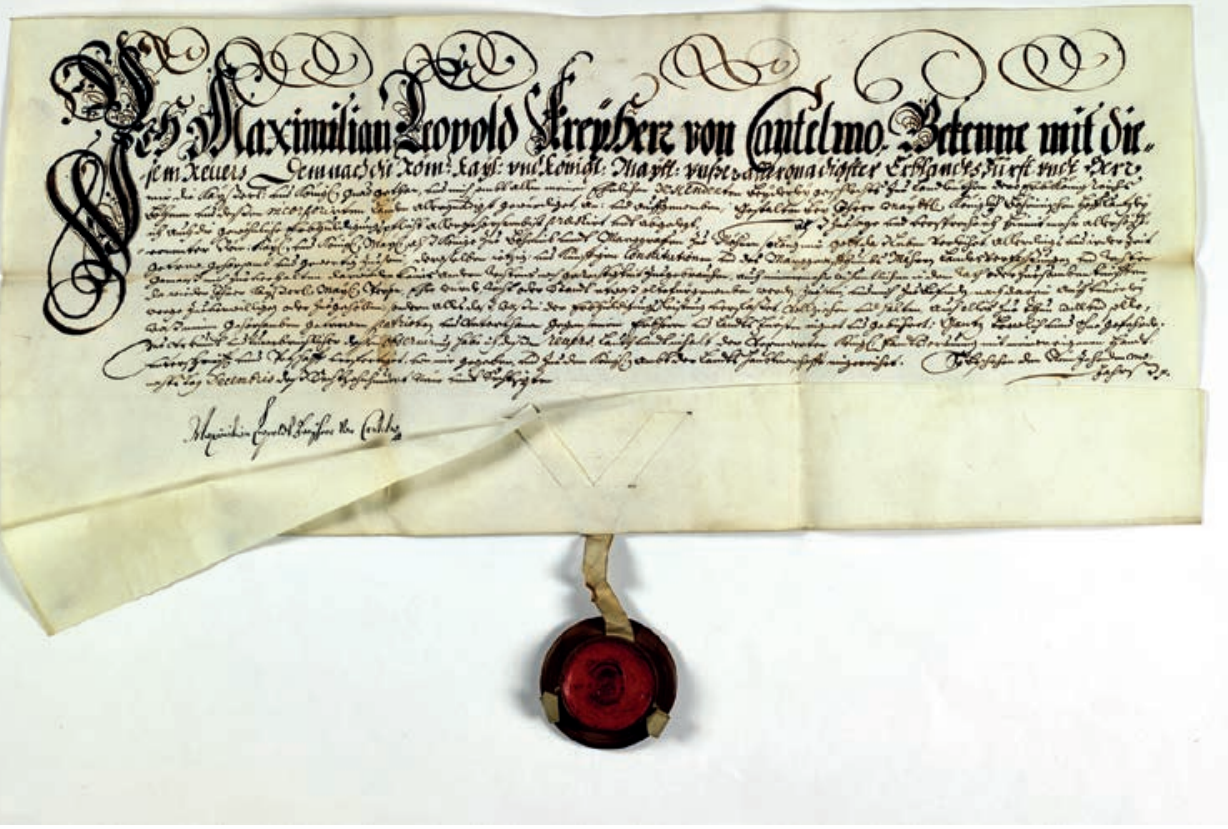

Obr. 13: Revers k zemi Maximiliana Leopolda svobodného pána Cantelma, 19. 12. 1669 (MZA, A 2 Reversy k zemi, R 62) 


\section{The "Majestätsquaterne" of the Moravian Land Registries. Admission to the Estates in Moravia after 1628 and Written Records of them in the Years 1642-1852}

The study is focused on analyzing the so-called "Majestätsquaterne", special series of the Moravian Land Registers (Landtafeln), which recorded the admission of new members to the community of Moravian land estates in the period 1642-1852. After the defeat of the Bohemian Revolt, the following conditions were imposed for the admission of estates (so-called habilitation in the land): possession of an incolat (a royal license to freely acquire and dispose of land property, so-called table estates), swearing a personal oath of loyalty to the monarch (juramentum fidelitatis) and making a written oath to uphold the constitution, laws, and customs of the land (Relation to the Land / Revers zum Lande). Both institutions of the Court (the Bohemian Court Chancellery and its successors) and land authorities (the Moravian Royal Tribunal and the Chancellery of Moravian Land Registers) were involved in the habilitation process in the land, producing documents which were then tabulated into Majestätsquaterne (or, sometimes, into quaternaries of oaths of loyalty in the period 1671-1781). The applicant's Relation to the Land for registration was supplied by the land registry. The applicant submitted documents demonstrating the possession of an incolat and the required aristocratic origin associated with it (originals of incolat and ennoblement charters, confirmation from the Court Chancellery or certified extracts from the Land Registers). The actual registration was carried out according to a compositional scheme which was completed in the second half of the 17th century and was used until the end of quaternary governance in the middle of the 19th century. Over time, there was a gradual decline in the number of registred documents. The deposits make it possible to observe the changes in the registred documents (ennoblement and incolat documents, intimation of the Court Chancellery and the land government, Relation to the Land) in terms of genetic as well as systematic and analytical diplomatics. The admission into the land, including Majestätsquaterne, disappeared in the middle of the 19th century, when the society of estates was replaced by civil society. 
